\title{
ANALISIS EFISIENSI RELATIF TERHADAP PEMANFAATAN ASET TETAP DENGAN MENGGUNAKAN DATA ENVELOPMENT ANALYSIS (STUDI PADA PEMERINTAH DAERAH PROVINSI NTB)
}

\author{
Jamaludin ${ }^{1)}$ \\ 1) dosen universitas pamulang, email : amaludinseimecdev@gmail.com
}

\section{ARTICLES}

INFORMATION

ABSTRACT

JURNAL SEKURITAS

(Saham, Ekonomi, Keuangan dan Investasi )

Vol.2, No.2, Januari 2019

Halaman : $33-59$

C LPPM \& Prodi Manajemen

UNVERSITAS PAMULANG

ISSN (online) : 2581-2777

ISSN (print) : :2581-2696

Keyword:

Data Envelopment Analysis, Efisiensi, SKPD..

JEL. classification :

C33, G21, G34, N25

\section{Contact Author :}

PRODI MANAJEMEN UNPAM

JL.Surya Kencana No.1 Pamulang

Tangerang Selatan - Banten

Telp. (021) 7412566, Fax (021) 7412491 Email :

jurnalfinance.unpam@gmail.com
Penelitian ini dilakukan dengan tujuan memperoleh bukti empiris terkait dengan Analisis Efisiensi relatif Terhadap Pemanfaatan Aset Tetap Dengan Menggunakan Data Envelopment Analysis (Studi Pada Pemerintah Daerah Provinsi NTB).hasil analisis Data Envelopment Analysis (DEA) menunjukkan dari tujuh belas Satuan Kerja Perangkat Daerah yang ditetapkan sebagai lembaga teknis daerah yang memiliki target pencapaian pendapatan asli daerah hanya terdapat 6 Satuan Kerja Perangkat Daerah saja yang efisien dalam mengelola dan memanfaatkan aset tetap (tanah dan bangunan) dengan nilai efisien relatif sebesar 100 persen. Satuan Kerja Perangkat Daerah tersebut antara lain: Badan Perencanaan Pembangunan Daerah (Bappeda), Dinas Pendapatan Daerah (Dispenda), Departemen Sosial Kependudukan dan Catpil, Rumah Sakit Jiwa (RSJ), Badan Lingkungan Hidup dan Penelitian (BLHP), dan Dinas Koperasi dan UMKM. Sedangkan masih terdapat 11 Satuan Kerja Perangkat Daerah lagi yang belum efisien dengan skor efisien di bawah 100 persen.

The research aimed to obtain empirical evidence related to Relative Efficiency Analysis on Utilization of Fixed Assets Using Data Envelopment Analysis (Study on Local Government of NTB Province). In accordance with the results of the Data Envelopment Analysis (DEA) analysis shows that out of seventeen Local Government Work Units which are designated as regional technical bodies with local revenue target achievements there are only 6 Regional Work Units that are efficient in managing and utilizing fixed assets (land and building) with a relative efficient value of 100 percent. These regional work units include: the Regional Development Planning Board (Bappeda), the Regional Revenue Service (Dispenda), the Department of Social Affairs and the Catpile, the Mental Hospital (RSJ), the Environment and Research Agency (BLHP), and the Dinas Koperasi and UMKM . While there are still 11 units of the Regional Devices that are not yet efficient with efficient scores below 100 percent. 


\section{A. Pendahuluan}

Otonomi daerah mempunyai konsekuensi bahwa peran pemerintah pusat akan semakin kecil, sebaliknya peran pemerintah daerah semakin besar dalam pembangunan daerah/wilayahnya. Pemerintah daerah dituntut memiliki kemandirian dalam membiayai sebagian besar anggaran pembangunannya. Oleh karena itu pemerintah daerah harus dapat melakukan optimalisasi sumber-sumber penerimaan daerahnya.

Berlakunya Undang-undang nomor 32 tahun 2004 tentang pemerintahan daerah dan Undang-undang nomor 33 tahun 2004 tentang perimbangan keuangan antara pemerintah pusat dan daerah memberikan kesempatan yang terbuka bagi daerah agar membangun dan mengembangkan daerah sesuai dengan kebutuhan dan prioritasnya masing-masing. Di keluarkannya undangundang ini memberikan konsekuensi logis bagi masing-masing daerah untuk bertanggung jawab atas pengalokasian dana yang dimiliki dengan cara yang efesien dan efektif, khususnya dalam peningkatan kesejahteraan dan pelayanan umum kepada masyarakat.

Penyerahan wewenang kepada pemerintah daerah untuk mengatur dan bertanggung jawab pada bidang pekerjaan umum, kesehatan, pendidikan, kebudayaan, pertanian, perhubungan, industri, dan perdagangan, penanaman modal, lingkungan hidup, pertanahan, koperasi dan tenaga kerja merupakan implikasi dari kebijakan desentralisasi dan otonomi daerah yang diatur dalam UU. 32 tahun 2004, sedangkan dalam bidang pertahanan keamanan, peradilan, moneter, fiskal dan agama masih menjadi wewenang pemerintah pusat.

Sejalan dengan tujuan pembangunan daerah, Tujuan Undang-undang nomor 32 tahun 2004 adalah untuk meningkatkan kesejahteraan rakyat dengan selalu memperhatikan kepentingan dan aspirasi masyarakat, memelihara keserasian dan mencegah ketimpangan antar daerah. Dalam penerapan UU. ini daerah dihadapkan pada permasalahan, antara lain adalah masalah keuangan daerah, di antaranya: dana alokasi umum (DAU) menjadi sumber penerimaan utama yang penting bagi semua daerah, pendapatan daerah yang hanya memberikan kontribusi sebesar $40 \%$, adanya gap dan hasil, dan adanya asset daerah yang belum optimal dimanfaatkan oleh daerah sebagai alternatif sumber keuangan daerah. Selain permasalahan keuanagan daerah, permasalahan lain yang muncul adalah masalah pembangunan daerah, di antaranya: adanya tuntutan akan akuntabilitas dan transparansi publik, kesiapan dari SDM dan organisasi dalam hal ini adalah kesiapan daerah dalam melaksanakan otonomi daerah dan kesiapan dalam memahami konsekuensi dalam otonomi daerah, belum adanya perencanaan yang matang yang berkaitan dengan potensi dan kekhasan daerah.

Salah satu sektor yang dapat diharapkan menjadi pendapatan daerah terutama di perkotaan adalah melalui sektor properti (aset tetap). Untuk menghadapi otonomi daerah, pemerintah daerah tidak hanya mengoptimalkan pada potensi pajak dari sektor properti saja, tetapi juga harus mengetahui jumlah dan sejauh mana pemanfaatan aset properti yang dimiliki pemerintah daerah saat ini. Manajemen aset properti ini sangat penting diketahui karena di samping sebagai penentuan aktiva tetap dalam faktor penambah dalam total aset daerah juga dapat dimanfaatkan sebagai salah satu sumber pendapatan yang menopang pendapatan asli daerah. 
Salah satu kunci dari keberhasilan pengelolaan ekonomi daerah adalah manajemen aset. Pentingnya manajemen aset secara tepat dan berdayaguna, dengan didasari prinsip pengelolaan yang efisien dan efektif, diharapkan akan memberi kekuatan terhadap kemampuan pemerintah dalam membiayai pembangunan daerahnya yang tercermin dalam Pendapatan Asli Daerah (PAD). Pemerintah daerah dapat menciptakan sumber pendapatan dengan cara melakukan langkah strategis untuk mengoptimalkan aset milik pemerintah daerah yang saat ini dikategorikan masih belum optimal serta mengevaluasi ketidakefisienan yang idle milik pemerintah daerah yang membutuhkan biaya operasional dan pemeliharaan yang besar. Aset daerah merupakan sumberdaya penting bagi pemerintah daerah sebagai penopang utama pendapatan asli daerah.

Oleh karena itu, penting bagi pemerintah daerah untuk dapat melakukan manajemen aset secara memadai. Dalam manajemen aset, pemerintah daerah harus menggunakan pertimbangan aspek perencanaan kebutuhan dan penganggaran, pengadaan, penerimaan, penyimpanan dan penyaluran, penggunaan, penatausahaan, pemanfaatan atau penggunaan, pengamanan dan pemeliharaan, penilaian, penghapusan, pemindahtanganan, pembinaan, pengawasan dan pengendalian, pembiayaan dan tuntutan ganti rugi agar aset daerah mampu memberikan kontribusi optimal bagi pemerintah daerah yang bersangkutan sehingga arah pembangunan di Bidang Pengelolaan Aset Daerah dapat terintegrasi dan terprogram dengan baik.

Kelangsungan manajemen aset dalam menjalankan peranannya dipengaruhi berbagai macam faktor, seperti inventarisasi aset, legal audit set, penilaian aset, dan optimalisasi pemanfaatan aset, ketika pemerintah daerah sudah memperhatikan halyang demikian maka ada peluang aset-aset tersebut dengan mudah dimanfaatkan dan ;ebih efisien. kemampuannya untuk terus stabil dalam menghasilkan pendapatan. Pentingnya peran manajemen aset tersebut membuat masing-masing SKPD dituntut untuk efisien dalam menjalankan kegiatannya mengelola dan memanfaatkan aset daehnya. Hal ini karena efisiensi merupakan salah satu prinsip yang merupakan landasan dalam menyusun program pemerintah daerah.

Aset daerah merupakan sumberdaya penting bagi pemerintah daerah sebagai penopang utama pendapatan asli daerah. Oleh karena itu, penting bagi pemerintah daerah untuk dapat melakukan manajemen aset secara memadai. Dalam manajemen aset, pemerintah daerah harus menggunakan pertimbangan aspek perencanaan kebutuhan dan penganggaran, pengadaan, penerimaan, penyimpanan dan penyaluran, penggunaan, penatausahaan, pemanfaatan atau penggunaan, pengamanan dan pemeliharaan, penilaian, penghapusan, pemindahtanganan, pembinaan, pengawasan dan pengendalian, pembiayaan dan tuntutan ganti rugi agar aset daerah mampu memberikan kontribusi optimal bagi pemerintah daerah yang bersangkutan sehingga arah pembangunan di Bidang Pengelolaan Aset Daerah dapat terintegrasi dan terprogram dengan baik. Berikut adalah tabel Nilai aset tetap, target PAD dan Realisiasi PAD Provinsi NTB. 


\section{B. Perumusan Masalah}

Rumusan masalah dalam penelitian ini adalah bagaimanakah efisiensi relatif dari ke 16 Satuan Kerja Perangkat Daerah (SKPD) Provinsi NTB?

\section{Tujuan Penelitian}

Tujuan dari penelitian ini adalah untuk mengetahui tingkat efisiensi relatif Satuan Kerja Perangkat Daerah (SKPD) Provinsi NTB.

\section{Landasan Teori}

\subsection{Definisi Aset}

Standar Akuntansi Pemerintahan dalam PSAP Nomor 07-1 mendefinisikan aset adalah sumber daya ekonomi yang dikuasai dan/atau dimiliki oleh pemerintah sebagai akibat dari peristiwa masa lalu dan dari mana manfaat ekonomi dan/atau sosial di masa depan diharapkan dapat diperoleh, baik oleh pemerintah maupun masyarakat, serta dapat diukur dalam satuan uang, termasuk sumber daya nonkeuangan yang diperlukan untuk penyediaan jasa bagi masyarakat umum dan sumber-sumber daya yang diperlihara karena alasan sejarah dan budaya.

Sementara itu, pengertian aset secara umum menurut Siregar (2004:178) adalah barang (thing) atau sesuatu barang (anything) yang mempunyai nilai ekonomi (economic value), nilai komersial (commercial value) atau nilai tukar (exchange value) yang dimiliki oleh badan usaha, instansi atau individu (perorangan).

Menurut Siregar (2004:178) pengertian aset bila dikaitkan dengan properti maka dapat dijabarkan melalui beberapa aspek, antara lain:

$\checkmark$ memiliki nilai ekonomis yang terkait dengan nilai pemanfaatan tertinggi dan terbaik (highest and best use);

$\checkmark$ menghasilkan pendapatan dari pengoperasian properti;

$\checkmark$ memiliki fisik, fungsi dan hak penguasaan yang baik;

$\checkmark$ economical life-time yang panjang.

Aset tetap menurut pernyataan Standar Akuntansi Pemerintahan Nomor 07 adalah aset berwujud yang mempunyai masa manfaat lebih dari 12 (dua belas) bulan untuk digunakan dalam kegiatan pemerintah atau dimanfaatkan oleh masyarakat umum. Peraturan Menteri Dalam Negeri Nomor 17 Tahun 2007 dan Standar Akuntansi Pemerintahan mengklasifikasikan aset tetap dan barang inventaris sebagai berikut:

a. tanah;

b. peralatan dan mesin;

c. gedung dan bangunan;

d. jalan, irigasi, dan jaringan;

e. aset tetap lainnya; dan

f. konstruksi dalam pengerjaan.

Terminologi "aset negara" dalam tulisan ini memiliki makna yang sama dengan Barang Milik Negara sebagaimana dimaksud dalam Undang-Undang Nomor 1 Tahun 2004 tentang Perbendaharaan Negara dan Peraturan Pemerintah Nomor 6 tahun 2006 tentang Pengelolaan Barang Milik Negara/Daerah, namun memiliki makna yang lebih sempit dari "kekayaan negara" dalam terminologi hukum dan mengandung makna yang lebih luas dari "aset tetap" yang biasa digunakan dalam terminologi akuntansi. 
Secara lebih spesifik Peraturan Pemerintah (PP) Republik Indonesia Nomor 6 tahun 2006 tentang Pengelolaan Barang Milik Negara/ Daerah menegaskan bahwa barang milik negara adalah semua barang yang dibeli atau diperoleh atas beban APBN atau berasal dari perolehan lainnya yang sah, sedangkan barang milik daerah adalah semua barang yang dibeli atau diperoleh atas beban APBD atau berasal dari perolehan lainnya yang sah yang meliputi:

a. barang yang diperoleh dari hibah/sumbangan atau yang sejenis;

b. barang yang diperoleh sebagai pelaksanaan dari perjanjian/kontrak;

c. barang yang diperoleh berdasarkan ketentuan peraturan perundangundangan; atau

d. barang yang diperoleh berdasarkan putusan pengadilan yang telah memperoleh kekuatan hukum tetap.

Adapun penggolongan barang milik daerah dalam Permendagri No 17 Tahun 2007 meliputi:

1) tanah, meliputi: tanah perkampungan, tanah pertanian, tanah perkebunan, kebun campuran, hutan, tanah kolam ikan, danau/ rawa, sungai, tanah tandus/rusak, tanah alang-alang dan padang rumput, tanah penggunaan lain, tanah bangunan dan tanah pertambangan, tanah badan jalan dan lain-lain sejenisnya.

2) peralatan dan mesin, meliputi:

$\checkmark$ alat-alat besar, terdiri dari alat-alat besar darat, alat-alat besar apung, alat-alat bantu dan lain-lain sejenisnya;

$\checkmark$ alat-alat angkutan, terdiri dari alat angkutan darat bermotor, alat angkutan darat tak bermotor, alat angkut apung bermotor, alat angkut apung tak bermotor, alat angkut bermotor udara, dan lain-lainnya sejenisnya;

$\checkmark$ alat-alat bengkel dan alat ukur, terdiri dari alat bengkel bermotor, alat bengkel tak bermotor, dan lain-lain sejenisnya;

$\checkmark$ alat-alat pertanian/peternakan, terdiri dari alat pengolahan tanah dan tanaman, alat pemeliharaan tanaman /pasca penyimpanan dan lain-lain sejenisnya;

$\checkmark$ alat-alat kantor dan rumah tangga dan lain-lain sejenisnya;

$\checkmark$ alat studio, alat komunikasi dan lain-lain sejenisnya;

$\checkmark$ alat-alat kedokteran seperti alat kedokteran umum, alat kedokteran gigi, alat kedokteran Keluarga Berencana, alat kedokteran mata, alat kedokteran THT, alat Rontgen, alat farmasi, dan lain-lain sejenisnya;

$\checkmark$ alat-alat laboratorium, seperti unit alat laboratorium, alat peraga/praktek sekolah dan lain-lain sejenisnya;

$\checkmark$ alat-alat keamanan, seperti senjata api, persenjatan non senjata api, amunisi, senjata sinar dan lain-lain sejenisnya;

3) gedung dan bangunan, meliputi:

4) bangunan gedung, seperti bangunan gedung tempat kerja, bangunan gedung, bangunan instalansi, bangunan gedung tempat ibadah, rumah tempat tinggal dan gedung lainnya yang sejenis;

5) bangunan monumen, seperti candi, monumen alam, monumen sejarah, tugu peringatan dan lain-lain sejenisnya;

6) jalan, irigasi dan jaringan, meliputi:

7) jalan, jembatan, terowongan dan lain-lain jenisnya; 
8) bangunan air irigasi, bangunan air pasang, bangunan air pengembangan rawa dan polde, bangunan air pengaman surya dan penanggul, bangunan air minum, bangunan air kotor dan bangunan air lain yang sejenisnya;

9) instalasi, seperti instalasi air minum, instalasi air kotor, instalasi pengolahan sampah, instalasi pengolahan bahan bangunan, instalasi pembangkit listrik, instalasi gardu listrik dan lain-lain sejenisnya;

10) jaringan, seperti jaringan air minum, jaringan listrik dan lain-lain sejenisnya;

11) aset tetap lainnya, meliputi:

12) buku dan perpustakaan

13) barang bercorak kesenian/kebudayaan seperti pahatan, lukisan alat-alat kesenian, alat olah raga, tanda penghargaan, dan lain-lain sejenisnya;

14) hewan/ternak dan tumbuhan, seperti seperti binatang ternak, binatang unggas, binatang melata, binatang ikan, hewan kebun binatang dan lain-lain sejenisnya. Tumbuhantumbuhan seperti pohon jati, pohon mahoni, pohon kenari, pohon asem dan lain-lain sejenisnya termasuk pohon ayoman/pelindung;

15) Kontruksi dalam pengerjaan

\subsection{Manajemen Aset Negara/Daerah}

Manajemen aset negara/daerah sering disebut pula sebagai pengelolaan barang milik negara/daerah. Pengelolaan tersebut dilaksanakan berdasarkan asas fungsional, kepastian hukum, transparansi dan keterbukaan, efisiensi, akuntabilitas, dan kepastian nilai. Untuk itu, pengelolaan aset negara/daerah tersebut merupakan tahapan menyeluruh sebagaimana diatur dalam Peraturan Menteri Dalam Negeri Nomor 17 Tahun 2007 tentang Pedoman Teknis Pengelolaan Barang Milik Daerah, bahwa pengelolaan barang milik daerah meliputi perencanaan kebutuhan dan penganggaran, pengadaan, penerimaan, penyimpanan dan penyaluran, penggunaan, penatausahaan, pemanfaatan, pengamanan dan pemeliharaan, penilaian, penghapusan, pemindahtanganan, pembinaan, pengawasan dan pengendalian, pembiayaan dan tuntutan ganti rugi.

Manajemen Aset Daerah adalah melaksanakan pengelolaan aset/ Barang Milik Daerah (BMD berdasarkan prinsip dasar-dasar manajemen aset terhadap aset/BMD dengan mengikuti landasan kebijakan yang diatur berdasarkan Undang-undang, Peraturan Pemerintah, Keppres, Kepmen, dan Surat Keputusan lainnya yang berhubungan dengan pengaturan/ pengelolaan aset daerah. Berikut ini adalah klasifikasi aset daerah berdasarkan penggunaan (Budisusilo, 2005):

1. Pemerintah:

- Perkantoran Pemda -

- Kantor Pemadam Kebakaran

- Kantor Polisi

- Rumah Sakit

2. Sosial: Taman, Rumah Dinas)

3. Surplus dan Investasi: (Tanah, Parkir, Property Investasi)

Sedangkan menurut Siregar (2004:518) menyebutkan bahwa manajemen aset terbagi atas lima tahapan kerja yang saling berhubungan sebagai berikut.

1. Inventarisasi aset, yang terdiri dari dua aspek yaitu inventarisasi fisik dan yuridis/legal. Aspek fisik mencakup: lokasi dan alamat, jenis dan bentuk aset, luas dan/atau jumlah aset, batas dan penunjuk khusus dan aspek legal terdiri atas status legal penguasaan atau 
pemilikan aset, batasan dan waktu penguasaan aset, ada atau tidaknya permasalahan legal.

2. Legal audit merupakan lingkup kerja manajemen aset yang berupa inventariasi status penguasaan aset, sistem dan prosedur penguasaan atau pengalihan aset, identifikasi dan mencari solusi atas permasalahan legal, dan strategi untuk memecahkan berbagai permasalahan legal yang terkait dengan penguasaan ataupun pengalihan aset.

3. Penilaian aset, terdiri dari review hasil inventarisasi aset, inspeksi, penetapan nilai sesuai kelompok aset, dan catatan aset tidak dapat dinilai dan aset potensial.

4. Optimalisasi aset, terdiri dari review daftar aset potensial, analisa highest and best use aset potensial, rekomendasi dan langkah lanjut aset yang dapat dioptimalkan perdayagunaannya, serta rekomendasi solusi aset yang tidak dapat dioptimalkan.

5. Pengawasan dan Pengendalian, terdiri dari pengawasan dan pengendalian satu atap, pengembangan aturan atau kebijakan pengambilan keputusan strategis tentang perolehan, pemilikan, dan disposisi pengaturan aset, serta pengembangan sumber daya manusia.

Menurut Prawoto (2017) tujuan manajemen aset adalah untuk menjaga agar nilai aset tersebut tetap tinggi dan mempunyai usia hidup yang panjang dengan menyediakan biaya operasi yang memadai sehingga mampu menghasilkan output yang tinggi secara efesien, memberikan kepuasan kepada pelanggan namun dengan tetap mengindahkan aspek peraturan perundangan yang berlaku dan aspek keselamatan kerja dan memberikan image yang baik kepada publik.

Nemmer (2007) berpendapat bahwa manajemen aset memiliki tujuan untuk meningkatkan proses pengambilan keputusan dan untuk mengalokasikan dana aset sebuah instansi sehingga pengembalian investasi yang terbaik diperoleh, manajemen aset mencakup semua proses, alat, dan data yang dibutuhkan untuk mengelola aset secara efektif untuk mencapai tujuan.

Hasting (2010) berpendapat bahwa fungsi manajemen aset dipelukan untuk memberikan pengetahuan aset dan kapasitas manajemen terkait dan kegiatan pendukung keputusan dalam konteks bisnis sebagai berikut: aset dan kemampuan aset terkait dalam perencanaan dan perencanaan pembangunan, perencanaan keberlanjutan, dan pengelolaan fasilitas.

Menurut Hambali (2010) ada lima tujuan manajemen aset, yaitu: kejelasan status kepemilikan aset, inventarisasi kekayaan daerah dan masa pakai aset, optimalisasi penggunaan dan pemanfaatan untuk meningkatkan pendapatan di mana aset berstatus sebagai idle capacity dapat dimanfaatkan sesuai peruntukkan yang ditetapkan, selain itu optimasisasi aset dapat mengidentifikasikan dan mengetahui pemanfaatannya untuk apa, diperuntukkan untuk siapa dan mendatangkan pendapatan bagi pengelola aset jika mampu mengelola aset sesuai dengan aturan yang berlaku, pengamanan asset, dan dasar penyusunan neraca.

\subsection{Efisiensi}

Konsep efisiensi pertama kali dikenal oleh Farrel (1957) yang merupakan tindak lanjut dari model yang diajukan oleh Debreu dan Koopmans (1951). Konsep pengukuran efisiensi Farrel dapat memperhitungkan input majemuk (lebih dari 1 input). Farrel mengatakan bahwa efisiensi sebuah perusahaan terdiri dari dua komponen yaitu efisiensi teknis (technical efficiency) dan efisiensi alokatif (allocative efficiency). 
Efisiensi teknis menunjukkan kemampuan perusahaan untuk mencapai output semaksimal mungkin dari sejumlah input. Efisiensi alokatif menunjukkan kemampuan perusahaan untuk menggunakan input dengan proporsi seoptimal mungkin pada tingkat harga input tertentu. Kedua komponen ini kemudian dikombinasikan untuk menghasilkan ukuran efisiensi total atau efisiensi ekonomis/economic efficiency (Sitanggang, 2012: 2425).

Hasibuan (2005) berpendapat bahwa efisiensi adalah perbandingan yang terbaik antara input (masukan) dan output (hasil antara dengan sumber-sumber yang digunakan), seperti halnya juga hasil optimal yang dicapai dengan penggunaan seumber yang terbatas. Efisiensi merupakan salah satu parameter kinerja yang secara teoritis mendasari seluruh kinerja sebuah organisasi.

Kumbhaker dan Lovell (2000) mengatakan bahwa efisiensi teknis merupakan salah satu dari komponen efisiensi ekonomi secara keseluruhan. Tetapi dalam rangka mencapai efisiensi ekonominya suatu perusahaan harus efisien secara teknis. Untuk mencapai tingkat keuntungan yang maksimal, sebuah perusahaan harus dapat berproduksi pada tingkat output yang optimal dengan jumlah input tertentu (efisiensi teknis) dan menghasilkan output dengan kombinasi yang tepat pada tingkat harga tertentu (efisiensi alokatif). Konsep pengukuran efisiensi dapat dilihat baik dari sisi input (input-oriented) maupun fokus pada sisi output (output-oriented), yang pada akhirnya kedua pendekatan ini yang secara konsisten akan menghasilkan kesimpulan yang sama tentang efisiensi relatif sebuah perusahaan terhadap sekawannya (lihat Sitanggang, 2012: 25).

Cooper et. al. (2003) yang menyatakan bahwa efisiensi teknik dapat dicapai dengan sempurna (100 persen) jika dan hanya jika dalam satu unit usaha tidak input atau output yang ditingkatkan tanpa menjadikan input dan output yang lain menjadi lebih buruk. Artinya, sebuah unit usaha dikatakan efisiensi teknis saat tidak dapat menaikkan beberapa output atau mengurangi beberapa input tanpa menghilangkan input lain. Efisiensi dalam menggunakan input akan menghasilkan produktifitas yang tinggi, yang merupakan tujuan dari setiap organisasi apapun bidang kegiatannya. Hal yang paling rawan adalah apabila efisiensi selalu diartikan sebagai penghematan, karena bisa mengganngu operasi, sehingga pada akhirnya akan mengganggu hasil akhir. Hal ini disebabkan karena sasarannya tidak tercapai dan produktifitanya juga akan tidak setinggi yang diharapkan (lihat Sitanggang, 2012: 26).

Kalirajan dan Shan (1994: 4) menyatakan sebagai salah satu ukuran kinerja dari suatu organisasi, ada tiga kegunaan yang diperoleh dari tindakan mengukur efisiensi, yaitu: pertama sebagai tolak ukur untuk memperoleh efisiensi relatif, sehingga akan mempermudah proses perbandingan antara unit kegiatan ekonomi yang satu dengan yang lainnya. Kedua, apabila terdapat variasi tingkat efisiensi di beberapa unit kegiatan ekonomi yang ada, maka dapat dilakukan analisis untuk mengidentifikasi faktor-faktor yang meyebabkan perbedaan tingkat efisiensi tersebut. Ketiga, akan ada analisis-analisis yang memiliki implikasi kebijakan untuk semakin memperbaiki tingkat efisiensi unit kegiatan ekonomi yang bersangkutan (lihat Pora 2012: 13),

Suwandi menyatakan bahwa terdapat 3 faktor yang dapat menyebabkan efisiensi, yaitu.

1. apabila dengan input yang sama dapat menghasilkan output yang lebih besar,

2. input yang lebih kecil dapat meghasilkan output yang sama, dan 
3. input yang lebih besar dapat menghasilkan output yang lebih besar lagi (lihat Sitanggang, 2012: 26),

a. Input-output sebagai ukuran efisiensi.

Konsep pengukuran efisiensi dapat dilihat baik dengan fokus pada sisi input (input oriened) merupakan fokus pada sisi output (output oriented). Kedua pendekatan ini analog dengan konsep primal dan dual dalam teknik operations research, yang bagaikan dua sisi mata uang, sehingga kedua pendekatan ini secara konsisten akan menghasilkan kesimpulan yang sama tentang efisiensi relatif sebuah perusahaan terhadap sekawannya.

Collie et. al. menyatakan pendekatan sisi input adalah diasumsikan sebuah perusahaan yang menggunakan dua jenis input, yaitu $\mathrm{x} 1$ dan $\mathrm{x} 2$, untuk memproduksi satu jenis output (y) dengan asumsi Constant Return to Scale (CRS). Asumsi CRS adalah jika kedua jenis input $\mathrm{x} 1$ dan $\mathrm{x} 2$ ditambah dengan jumlah persentase tersebut maka output juga akan meningkat dengan persentase yang sama (lihat Sitanggang , 20012: 27). Konsep efisiensi dari pendekatan sisi input dapat digambarkan berikut.

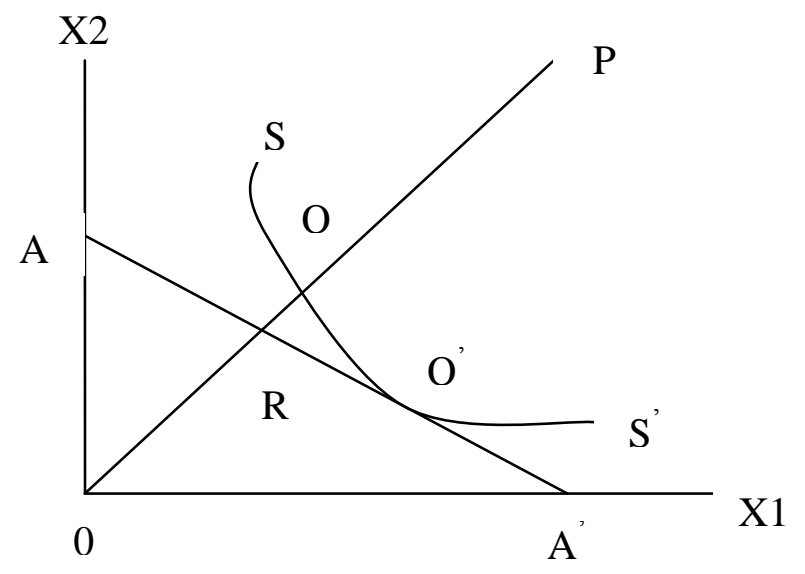

Sumber: Sitanggang (2012: 27)

Gambar Konsep efisiensi dari pendekatan sisi input

Berdasarkan Gambar diatas kurva SS' adalah kurva isoquant yang merupakan himpunan titik-titik perusahaan yang paling efisien dalam kumpulan sekawannya (fully efficient firms) atau perusahaan-perusahaan yang paling efisien secara teknis (fully technically efficient). Perusahaan yang berada pada titik $P$ adalah perusahaan yang tergolong kurang efisien. Perusahaan ini dapat menjadi perusahaan yang lebih efisien jika dapat mengurangi kedua jenis input nya, $\mathrm{x} 1$ dan x2, untuk memproduksi 1 unit output, sehingga perusahaan tersebut berada di titik Q. Jarak $P Q$ disebut sebagai potential improvement, yaitu berapa banyak kuantitas input dapat dikurangi secara proporsional untuk memproduksi kuantitas output yang sama. Ukuran efisiensi teknik sebuah perusahaan dalam kelompok sekawan (TEi) secara umum diukur dengan rasio.

$$
\mathrm{TE}=1-\mathrm{QP} / 0 \mathrm{P}=0 \mathrm{Q} / 0 \mathrm{P}
$$

$0 \leq \mathrm{TE} \leq 1$. Nilai Tei $=1$ menunjukkan bahwa perusahaan $\mathrm{I}$ adalah yang paling efisien secara teknis di antara kelompok sekawannya. 
Garis AA' adalah isocost yang menunjukkan rasio harga (price ratio) antara input 2 terhadap input 1. Efisien alokatif (AEi) perusahaan I yang berada pada titik $P$ ditunjukan oleh rasio.

$$
\text { Aei }=1-R Q / 0 Q=0 R / 0 Q
$$

Di mana $R Q$ menunjukkan pengurangan biaya produksi yang akan terjadi bila produksi dilakukan pada titik yang efisien baik secara teknis maupun secara alokatif, yaitu $Q$ titik $Q$ adalah efisien secara teknis, namun tidak efisien secara alokatif. Pendekatan sisi output sangat berlawanan dengan pendekatan pendekatan sisi input menjawab berapa banyak kuantitas input bisa dikurangi secara proporsional untuk memproduksi kuantitas output yang sama, pendekatan sisi output menjawab berapa banyak kuantitas output dapat ditingkatkan secara proporsional dengan kuantitas input yang sama. Asumsi sebuah perusahaan dengan 2 jenis output ( $\mathrm{y} 1$ dan $\mathrm{y} 2)$ dan 1 jenis input $(\mathrm{x})$ dalam rancangan CRS Gambar 2.6 akan menunjukkan konsep ukuran efisiensi dengan pendekatan sisi output.

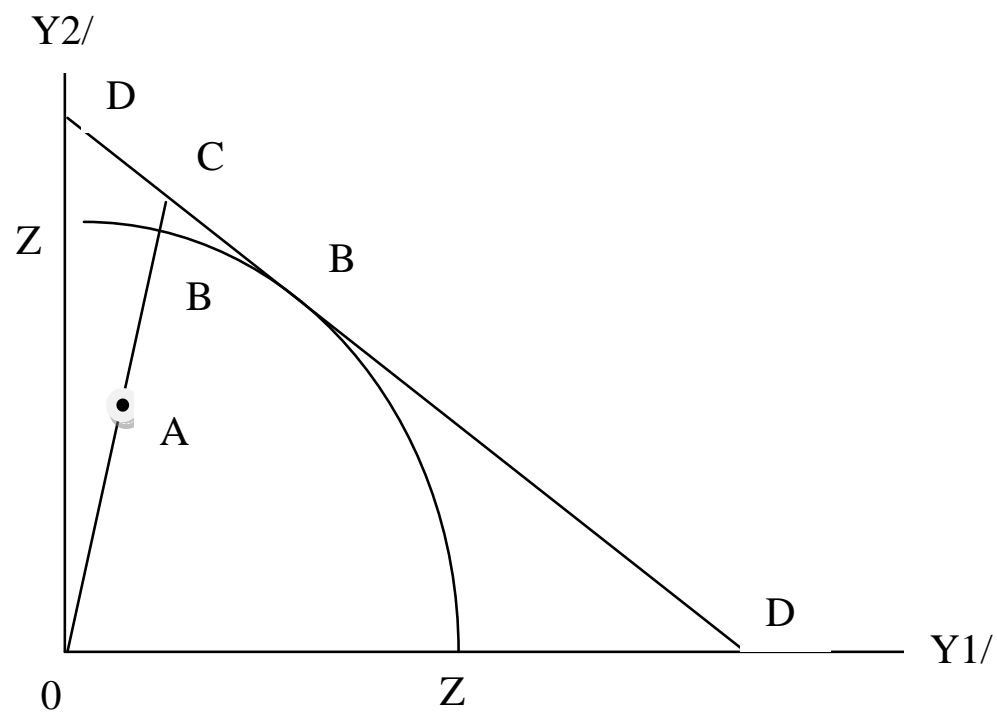

Sumber: Sitanggang (2012: 29)

Gambar Konsep efisiensi dengan pendekatan sisi output

Pada gambar di atas, kurva ZZ' adalah Kemungkinan Kurva Produksi (PPF), sedangkan garis DD' adalah isorevenue yang menunjukkan rasio harga kedua output. Titik $B$ adalah titik yang efisien secara teknis, sedangkan titik $A$ tidak efisien. Jarak $A B$ adalah besarnya potential improvement yang mungkin dilakukan perusahaan pada titik $A$ untuk menjadi perusahaan yang efisien secara teknis. Ukuran efisien teknis (TEi) untuk sebuah perusahaan adalah.

$$
\text { Tei }=1-\mathrm{AB} / 0 \mathrm{~B}=0 \mathrm{~A} / 0 \mathrm{~B}
$$

Jika kita memilki informasi tentang harga output, maka efisiensi alokatif (AEi) dapat dihitung dengan.

$$
\text { AEI } 1-B C / 0 C=0 B / 0 C
$$

Improvement ke titik $\mathrm{C}$ memiliki makna bahwa perusahaan di titik $\mathrm{B}$ masih dapat meningkatkan pendapatannya dengan berproduksi dititik yang efisien secara teknis dengan efisiensi alokatif, secara matematis.

$$
\text { Eei Tei } \times \text { Aei }=0 A / 0 B \times 0 B / 0 C=0 A / 0 C
$$


Ukuran efisiensi relatif, baik dengan pendekatan sisi input maupun output samasama membutuhkan pendefinisian garis pembatas (frontier) yang menunjukkan perusahaan-perusahaan yang secara relatif paling efisien dari pada kelompok sekawannya.

\subsection{Data Envelopment Analysis (DEA)}

Metoda Data Envelopment Analysis (DEA) dibuat sebagai alat bantu untuk evaluasi kinerja suatu aktifitas dalam sebuah unit entitas (organisasi). Pada dasarnya prinsip kerja model DEA adalah membandingkan data input dan output dari suatu organisasi data (decision making units, DMU) dengan data input dan output lainnya pada DMU yang sejenis. Perbandingan ini dilakukan untuk mendapatkan suatu nilai efisiensi.

Model Data Envelopment Analysis (DEA) dikembangkan pertama kali oleh Charnes, Cooper, dan Rhodes (1978), untuk mengevaluasi efisiensi relatif unit-unit pengambil keputusan atau Decision Making Units (DMU) dalam sebuah organisasi dengan memberi bobot pada input dan output. Model DEA menghitung efisiensi teknis untuk seluruh unit. Skor efisiensi untuk setiap unit adalah relatif, tergantung pada tingkat efisiensi dari unitunit lain yang di dalam sampel.

Avkiran (1999: 206) mengatakan DEA merupakan teknik pemrograman linier non parametrik yang menghitung perbandingan rasio antara output dan input untuk setiap unit yang dilaporkan sebagai nilai efisiensi relatif, di mana skor efisiensi biasanya dinyatakan antara nol dan satu atau 0 dan 100 persen. Unit pengambilan keputusan dengan skor kurang dari satu dianggap relatif tidak efisien terhadap unit-unit lain. Kegunaan utama dari DEA adalah terletak pada kemampuannya untuk menghasilkan perbaikan potensial (yakni target yang dicapai) untuk unit yang tidak efisien dan mengidentifikasi unit lain sebagai patokan. Efisiensi relatif dari Decision Making Unit didefinisikan sebagai rasio jumlah tertimbang output ke tertimbang jumlah input. Hal ini dapat ditulis sebagai berikut (Avkiran, 1999: 217).

$$
h_{0}=\frac{\sum_{r-1}^{s} u_{r} y_{r o}}{\sum_{i=1}^{m} v_{i} x_{i o}}
$$

Di mana:

$s \quad$ : jumlah output

$u_{r} \quad$ : berat $r$ output

$y_{\text {ro }} \quad$ : jumlah $r$ dihasilkan oleh DMU

$m \quad$ : jumlah input

$v_{i} \quad$ : berat input $\mathrm{i}$, dan

$x_{i o} \quad$ : jumlah input i yang digunakan oleh DMU tersebut

Widodo (2006: 265-266) menyatakan bahwa Data Envelopment Analysis (DEA) merupakan sebuah metoda pendekatan yang bersifat non parametrik yang didasarkan pada perhitungan programasi linear. DEA dapat dipergunakan untuk mengukur kinerja sebuah perusahaan daerah maupun bentuk usaha lain yang didefinisikan sebagai rasio antara output terbobot dengan input yang telah dibobot. Dengan menerapkan DEA maka analis dituntut untuk dapat menentukan bobot yang harus diberikan kepada input maupun output-nya. Bobot yang dipilih oleh DEA merupakan bobot tertinggi yang akan memaksimumkan rasio efisiensi relatifnya. Dalam perhitungan DEA terdapat dua metoda utama yaitu pendekatan secara grafis dan pendekatan secara linier dengan programasi linear. 
Kusmargiani (2006) menyatakan bahwa Data Envelopment Analysis (DEA) merupakan salah satu analisis non parametrik yang biasanya digunakan untuk mengukur efisiensi relatif baik antara organisasi bisnis yang berorientasi laba (profit oriented) maupun antarorganisasi atau pelaku kegiatan ekonomi yang tidak berorientasi laba (non profit oriented) yang dalam proses aktivitasnya melibatkan penggunaan input-input tertentu untuk menghasilkan output-output tertentu. Data Envelopment Analysis (DEA) juga dapat digunakan sebagai alat pengambilan kebijakan untuk meningkatkan efisiensi (lihat Wahyuni, 2001: 39).

Pada dasarnya terdapat dua jenis perhitungan DEA. Perhitungan pertama adalah dapat dilakukan dengan menggunakan metoda grafis. Metoda kedua adalah dengan menggunakan programasi linear. Perhitungan kedua ini selanjutnya dapt dilakukan dengan menggunakan berbagai macam alat simpleks maupun alat-alat perhitungan lainnya. Pendekatan secara grafis dapat kita pergunakan untuk membahas dasar teori yang berlaku pada metoda DEA. Programasi linear meminta analis untuk mendefinisikan fungsi tujuan yang akan dipecahkan dengan dibatasi oleh fungsi kendala. Fungsi tujuan yang dimaksud adalah rasio dari total output tertimbang terhadap total input tertimbangnya (Widodo, 2006: 266-269)

Konsep dasar Data Envelopment Analysis (DEA) adalah.

1. Positivity, artinya DEA mensyaratkan semua variabel input dan output bernilai positif $(>0)$.

2. Isotonicity, artinya antara variabel input dan output nya harus mempunyai hubungan yang isotonis, yaitu untuk setiap kenaikan/pertambahan jumlah input harus menghasilkan kenaikan setidaknya satu variabel output, dan tidak ada variabel output yang mengalami penurunan.

3. Jumlah Decision Making Unit (DMU) adalah tiga kali jumlah variabel input dan output-nya, untuk memastikan adanya degree of freedom.

4. Homogenitas, artinya DEA menuntut seluruh DMU memiliki variabel input dan output yang sama jenisnya (Wahyuni, 2017: 39).

Selanjutnya Wahyuni (2017: 40) menyatakan bahwa dalam menerapkan pendekatan Data Envelopment Analysis (DEA), terdapat asumsi yang mendasari yaitu.

1. DMU harus merupakan unit-unit yang homogenis, yaitu memiliki fungsi dan tujuan yang sama.

2. Jumlah ukuran DMU dari unit yang di sampel besarnya 2 atau 3 kali penjumlahan input dan output.

Widodo (2006: 266) menyatakan bahwa penggunaan metoda DEA memiliki beberapa keuntungan dibandingkan dengan metoda lainnya, meliputi: pertama; DEA mampu menghasilkan efisiensi bagi setiap unit kegiatan ekonomi yang dijalankan oleh pengambil keputusan, kedua; pengambil kebijakan dapat menyusun strategi perbaikan untuk memperbaiki kegiatan ekonomi yang memiliki efisiensi kurang dari 100 persen, ketiga; menghasilkan matriks efisiensi silang, artinya rasio output tertimbang terhadap input tertimbang yang kesemuanya dihitung dengan menggunakan setiap input maupun output dari setiap kegiatan ekonomi yang dilakukan. Selanjutnya, keuntungan tambahan dari DEA adalah: (1) kemampuan untuk mengidentifikasi sumber dan jumlah inefisiensi di setiap input dan setiap output untuk setiap entitas; (2) kemampuan untuk mengidentifikasi unit lain dari unit efisien 
digunakan untuk melakukan evaluasi dan mengidentifikasi sumber-sumber yang inefisiensi (Cooper, Seiford dan Tone, 2002: 14).

Model DEA digunakan sebagai perangkat untuk mengukur kinerja setidaknya memiliki 4 keunggulan dibandingkan dengan model lain, antara lain sebagai berikut.

1. Model DEA dapat mengukur banyak variabel input dan variabel output

2. Tidak diperlukan asumsi hubungan fungsional antara variabel-variabel yang diukur

3. Variabel input dan output dapat memiliki variabel yang berbeda.

Nilai-nilai yang dapat di lihat dari analisis DEA adalah sebagai berikut.

1. DEA menghasilkan efisiensi untuk setiap Unit Kegiatan Ekonomi (UKE) yang lain di dalam sampel. Angka efisiensi ini memungkinkan analis untuk mengenali Unit Kegiatan Ekonomi (UKE) yang paling membutuhkan perhatian dan merencanakan perbaikan bagi Unit Kegiatan Ekonomi (UKE) yang inefisien.

2. Jika suatu Unit Kegiatan Ekonomi (UKE) kurang efisien ( 0 persen $<$ efisien $<100$ persen), DEA menunjukkan satu atau sejumlah Unit Kegiatan Ekonomi (UKE) yang memiliki efisiensi sempurna (efisiensi $=100$ persen) dan seperangkat alat pengganda (multipliers) yang dapat digunakan oleh pengambil kebijakan untuk menyusun strategi perbaikan (PAU-SE UGM, 2000: 7).

Kelemahan DEA dibandingkan dengan metoda lain adalah DEA bersifat sample selection, kesalahan pengukuran bisa berakibat fatal, hanya mengukur efisiensi relatif dari DMU, dan bukan efisiensi absolut, uji hipotesis statistik atas hasil DEA sulit dilakukan karena itu sendiri merupakan pengukuran parametrik. Pengukuran efisiensi atas sejumlah DMU itu dilakukan secara bersama-sama. Dalam penelitian ini akan digunakan teknik analisis DEA dengan menggunakan pendekatan secara linier dengan programasi linier.

Pendekatan secara linear dengan linear programming. Program linear meminta analis untuk mendefinisikan fungsi tujuan yang akan dipecahkan dengan dibatasi oleh fungsi kendala. Fungsi tujuan yang dimaksud adalah rasio dari total output tertimbang terhadap total input tertimbangnya Widodo (2006: 269). Pemilihan variabel input dan output dalam penelitian didasarkan pada kedekatan hubungan antarvariabel. Artinya variabel input sangat erat kaitannya dengan pencapaian variabel output (Wahyuni, 2017: 41).

Input-output. Penentuan variabel input dan output merupakan langkah terpenting yang dilakukan dalam mengukur efisiensi dengan menggunakan DEA. Selanjutnya menentukan orientasi model, apakah bertujuan untuk memaksimalkan output atau meminimalkan input, yang mana hubungan antara variabel input dan variabel output apaka bersifat variable return to scale atau constant return to scale, karena keduanya tersebut merupakan aspek yang penting dalam teknik DEA. Hubungan antara input dan output yang bersifat Constant Return to Scale efisiensi teknis yang hendak dicapai tidak mencerminkan skala ekonomi yang efisien, dalam hubungan input dan output yang variabel return to scale menganggap efisiensi yang dicapai juga menggambarkan efisiensi dalam skala ekonomi.

Dalam penelitian ini variabel input yang peneliti gunakan adalah nilai aset tetap (tanah dan bangunan) yang dimiliki oleh masing-masing Satuan Kerja Perangkat Daerah (SKPD) Provinsi Nusa Tenggara Barat dan target pendapatan asli daerah (PAD) pada tahun 2017. Menjadi variabel output-nya adalah realisasi Pendapatan Asli Daerah (PAD) masing-masin SKPD Provinsi Nusa Tenggara Barat pada tahun 2017. 
Hubungan antara input dan output dalam penelitian ini adalah hubungan input dan output yang bersifat variable return to scale. Artinya hubungan tersebut menggambarkan efisiensi relatif dalam skala ekonomi, dalam hal ini dalam mengoptimalkan pengelolaan dan pemanfaatan aset tetap (tanah dan bangunan) tersebut.

\section{E. Metodologi}

Data yang digunakan dalam penelitian ini adalah merupakan data skunder. Data skunder merupakan data yang dikumpulkan dan disatukan oleh peneliti sebelumnya dan atau yang diterbitkan oleh instansi lainnya dan bisa diperoleh melalui catatan, arsip, jurnal, situs internet, dan buku-buku yang dapat menunjang kelangsungan penelitian ini. Data skunder diperoleh dari Sekretariat Daerah Provinsi Nusa Tenggara Barat dalam hal ini data tersebut diperoleh dari Biro Umum, dan Dinas Pendapatan Daerah (Dispenda) Provinsi Nusa Tenggara Barat. Penelitian ini digolongkan kedalam sebuah metode yang bersifat non parametrik yang didasarkan pada perhitungan program linear (Widodo, 2006: 265). Penelitian ini menggunakan alat analisis Data Envelopment Analysis (DEA) dengan menggunakan software komputer Warwick DEA (WDEA).

\section{F. Hasil dan Pembahasan}

DEA memberikan indikator efisiensi komparatif untuk mengevaluasi unit. Unit yang dianalisis disebut unit pengambilan keputusan (Decission Making Unit/DMU). Dalam DEA, efisiensi relatif dari DMU didefinisikan sebagai rasio dari total output tertimbang terhadap total input terbobot. Jika homogenitas dipertahankan, output dan input dapat dinyatakan dalam satuan pengukuran (Martin, 2003: 4).

Pengujian dengan menggunakan Data Envelopment Analysis (DEA) dalam penelitian ini adalah untuk mengetahui kinerja satuan kerja perangkat daerah yang efisien dalam mengelola dan memanfaatkan aset tetap (tanah dan bangunan). Dalam penelitian ini menggunakan 17 (tujuh belas) Dinas Provinsi NTB yang memiliki nilai aset dan target PAD.

Berikut adalah target PAD dan realisasi PAD dari ke 17 (tujuh belas) Dinas Provinsi NTB.

Tabel Daftra Target PAD dari Pemanfaatan Aset Tetap dan Realisasi PAD

Pemanfaatan Aset Tetap 17 SKPD Pemerintah Daerah Provinsi NTB Per 31 Desember 2017

\begin{tabular}{|r|l|r|r|}
\hline $\begin{array}{c}\text { N } \\
\text { o }\end{array}$ & Satuan Kerja Perangkat Daerah & Target PAD (Rp) & Realisasi PAD (Rp) \\
\hline 1. & Sekretariat DPRD & 1.347 .638 .716 & $786.142 .208,00$ \\
\hline 2. & Biro Umum & 2.370 .740 .556 & $1.255 .483 .310,00$ \\
\hline 3. & Dinas Pekerjaan Umum & 1.652 .875 .000 & $927.336 .697,00$ \\
\hline 4. & Dinas Perhubungan KOMINFO & 807.301 .000 & $519.340 .005,00$ \\
\hline 5. & Dinas Kesehatan (Dikes) & 32.631 .450 .860 & $2.684 .730 .333,00$ \\
\hline 6. & Rumah Sakit Umum (RSU) & 3.651 .000 .000 & $52.027 .661 .438,87$ \\
\hline 7. & Rumah Sakit Jiwa (RSJ) & 83.320 .000 & $197.744 .528,45$ \\
\hline 8. & Dinas Penidikan Pemuda dan Olahraga & & \\
\hline 9. & Dinas Sosial Kependudukan dan Capil & 106.900 .000 & $124.549 .721,00$ \\
\hline 10. & Dinas Tenaga Kerja dan Transmigrasi & 601.173 .200 & $510.521 .700,00$ \\
\hline 11. & Dinas Koperasi dan UMKM & 308.900 .000 & $486.876 .656,00$ \\
\hline
\end{tabular}




\begin{tabular}{|r|l|r|r|}
\hline 12. & Dinas Pendapatan Daerah & 519.971 .637 .668 & $521.574 .904 .859,49$ \\
\hline 13. & Badan Perencanaan Pembangunan \\
& Daerah & 4.800 .000 & $23.778 .800,00$ \\
\hline 14. & $\begin{array}{l}\text { Badan Lingkungan Hidup dan } \\
\text { Penelitian }\end{array}$ & 5.750 .000 & $27.661 .941,00$ \\
\hline 15. & Dinas Kebudayaan dan Pariwisata & 87.680 .000 & $102.788 .556,00$ \\
\hline 16. & Badan Kepegawaian Daerah dan Diklat & 300.000 .000 & $304.042 .000,00$ \\
\hline 17. & Badan Perpustakaan dan Arsip & 100.000 .000 & $100.149 .783,89$ \\
\hline
\end{tabular}

Sumber: Dinas Pendapatan Daerah Provinsi (Dispenda) NTB (data diolah)

Sesuai dengan Tabel diatas, sebenarnya terdapat 21 SKPD yang memiliki target dan realisasi PAD pada lingkungan Pemerintah Daerah Provinsi NTB. Akan tetapi dalam penelitian ini peneliti hanya menggunakan 17 SKPD. Digunakannya tujuh belas Satuan Kerja Perangkat Daerah (SKPD) sebagai unit dalam perhitungan DEA adalah merupakan hasil analisis peneliti pada laporan nilai aset dan laporan PAD Provinsi NTB per 31 Desember 2017. Dalam penelitian ini, peneliti memilih SKPD yang memiliki nilai aset tetap (tanah dan bangunan), target PAD, dan Realisasi PAD per 31 Desember 2017.

Dari hasil pengujian DEA menunjukkan bahwa pada Pemerintah Daerah Provinsi Nusa Tenggara Barat pada keadaan Constant Return to Scale (CRS) terdapat lima Satuan Kerja Perangkat Daerah (SKPD) yang mencapai efisiensi relatif 100 persen pada tahun 2017. SKPD tersebut antara lain Badan Lingkungan Hidup dan Penelitian (BLHP), Dinas Pendapatan Daerah (Dispenda), Badan Perencanaan Pembangunan Daerah (Bappeda), Rumah Sakit Jiwa (RSJ), dan Dinas Koperasi dan UMKM. Akan tetapi pada keadaan Variable Return to Scale (VRS) perhitungan DEA menunjukkan terdapat terdapat enam Satuan Kerja Perangkat Daerah (SKPD) yang mencapai efisiensi relatif pada tahun 2017, diantaranya adalah: Badan Perencanaan Pembangunan Daerah (Bappeda), Dinas Pendapatan Asli Daerah (Dispenda), Departemen Sosial Kependudukan dan Catatan Sipil (Depsoskep dan Catpil), Rumah Sakit Jiwa (RSJ), Badan Lingkungan Hidup dan Penelitian (BLHP), dan Dinas Koperasi dan UMKM (Diskop dan UMKM). Dalam penelitian ini peneliti menjelaskan pada keadaan Variable Return to Scale (VRS) karena memiliki skala ekonomi (economic scale).

Pada kriteria VRS keenam SKPD tersebut dikatagorikan sebagai SKPD yang mampu mengelola dan memanfaatkan aset tetap (tanah dan bangunan) dengan optimal dengan nilai efisiensi relatif mencapai 100 persen. Sebelas SKPD lainnya (Dephubkominfo, Sekretariat DPRD, BKD dan Diklat, Dikpora, Biro Umum, Bapusda dan Arsip, Dikes, RSU, Dinas PU, Disnakertrans, Dishubpar) mengalami inefisiensi dengan nilai efisiensi $<100$ persen.

Berikut adalah tabel yang menunjukkan besarnya tingkat efisiensi CRS dan VRS pada tujuh belas SKPD Pemerintah Daerah Provinsi NTB. Dari hasil analisis tersebut akan dijelaskan hasil analisis secara teknis maupun ekonomis dan supaya perbaikan yang dapat dilakukan. Dalam tabel menunjukkan bahwa angka skor efisiensi di setiap SKPD sangat variatif yaitu mulai dari angka skor efisiensi costant return to scale (CRS) yang paling rendah 26,52 persen dan untuk angka skor efisiensi Variable Return to Scale (VRS) mulai angka skor efisiensi 41,88 persen sampai pada angka skor efisiensi tertinggi 100 persen.. 
Tabel Nilai Efisiensi Relatif CRS dan VRS

17 SKPDPemerintah Daerah Provinsi NTB, 2017

\begin{tabular}{|l|l|c|c|c|}
\hline No & \multicolumn{1}{|c|}{ SKPD } & $\begin{array}{c}\text { Skor } \\
\text { efisiensi } \\
\text { CRS } \\
\text { (persen) }\end{array}$ & $\begin{array}{c}\text { Skor } \\
\text { efisiensi } \\
\text { VRS } \\
\text { (persen) }\end{array}$ & Keterangan \\
\hline 1. & Sekretariat DPRD & 41,36 & 42,92 & IRS \\
\hline 2. & Biro Umum & 26,52 & 42,23 & IRS \\
\hline 3. & Dinas Pekerjaan Umum (Dinas PU) & 35,26 & 42,69 & IRS \\
\hline 4. & Dinas Perhubungan KOMIINFO & 35,53 & 41,88 & IRS \\
\hline 5. & Dinas Kesehatan (Dikes) & 67,52 & 67,65 & IRS \\
\hline 6. & Rumah Sakit Umum (RSU) & 85,80 & 97,63 & IRS \\
\hline 7. & Rumah Sakit Jiwa (RSJ) & 100,00 & 100,00 & ORS \\
\hline 8. & $\begin{array}{l}\text { Dinas Pendidikan, Pemuda dan } \\
\text { Olahraga (DIKPORA) }\end{array}$ & 92,96 & 93,53 & IRS \\
\hline 9. & $\begin{array}{l}\text { Dinas Sosial Kependudukan dan } \\
\text { Capil }\end{array}$ & 88,96 & 100,00 & IRS \\
\hline 10. & $\begin{array}{l}\text { Dinas Tenaga Kerja dan } \\
\text { Transmigrasi }\end{array}$ & 56,24 & 56,36 & IRS \\
\hline 11. & Dinas Koperasi UMKM & 100,00 & 100,00 & ORS \\
\hline 12. & $\begin{array}{l}\text { Dinas Pendapatan Daerah } \\
\text { (Dispenda) }\end{array}$ & 100,00 & 100,00 & ORS \\
\hline 13. & $\begin{array}{l}\text { Badan Perencanaan Pembangunan } \\
\text { Daerah (Bappeda) }\end{array}$ & 100,00 & 100,00 & ORS \\
\hline 14. & $\begin{array}{l}\text { Badan Lingkungan Hidup dan } \\
\text { Penelitian (BLHP) }\end{array}$ & 100,00 & 100,00 & ORS \\
\hline 15. & Dinas Kebudayaan dan Pariwisata & 72,51 & 80,94 & IRS \\
\hline 16. & $\begin{array}{l}\text { Badan Kepegawaian Daerah dan } \\
\text { Diklat }\end{array}$ & 62,82 & 62,89 & IRS \\
\hline 17. & Badan Perpustakaan dan Arsip & 44,72 & 53,60 & IRS \\
\hline
\end{tabular}

Sumber: Perhitungan DEA (data diolah)

Pada Tabel diatas dijelaskan perbedaan skor efisiensi relatif dari Contstant Return to Scale (CRS) dan Variable Return to Scale (VRS).

\section{Hasi analisis Contstant Return to Scale (CRS)}

Pada tahun pengamatan 2017 dari tujuh belas SKPD yang ada setelah dihitung tingkat efisiensi relatifnya dengan Data Envelopment Analysis (DEA) menggunakan asumsi Constant Return to Scale (CRS) terdapat lima SKPD yang sudah mampu mencapai tingkat efisiensi relatif sebesar 100 persen. SKPD tersebut adalah Badan Lingkungan Hidup dan Penelitian (BLHP), Dinas Pendapatan Daerah (Dispenda), Badan Perencanaan Pembangunan Daerah (Bappeda), Rumah Sakit Jiwa (RSJ), dan Dinas Koperasi dan UMKM. Akan tetapi masih terdapat dua belas SKPD yang skor efisiensi relatifnya di bawah 100 persen. SKPD tersebut antara lain Sekretariat DPRD 41,36 persen, Biro Umum 26,52 persen, Dinas Pekerjaan Umum 35,26 persen, Dinas Perhubungan dan KOMINFO 35,53 persen, Dinas Kesehatan 67,52 persen, Rumah Sakit Umum Daerah 85.80 persen, Dinas Pendidikan dan Olahraga 92,96 persen, Departemen Sosial Kependudukan dan Catpil 88,96 persen, Dinas Tenaga Kerja dan Transmigrasi 56,24 persen, Dinas Kebudayaan dan Pariwisata 72,51 persen, 
Badan Kepegawaian Daerah dan Diklat 62,82 persen, Badan Perpustakaan Daerah dan Arsip 44,72 persen. Kesebelas SKPD ini masih dikatagorikan sebagai SKPD yang mengalami inefisiensi dalam mengelola dan memanfaatkan aset tetap (tanah dan bangunan).

2. Hasil analisis Variable Return to Scale (VRS).

Pada tahun pengamatan 2017 dari tujuh belas SKPD yang ada setelah dihitung tingkat efisiensi relatifnya dengan Data Envelopment Analysis (DEA) menggunakan asumsi Variable Return to Scale (VRS) terdapat 6 SKPD yang sudah mampu mencapai tingkat efisiensi relatif sebesar 100 persen. SKPD tersebut adalah Badan Lingkungan Hidup dan Penelitian (BLHP), Dinas Pendapatan Daerah (Dispenda), Badan Perencanaan Pembangunan Daerah (Bappeda), Rumah Sakit Jiwa (RSJ), Dinas Koperasi dan UMKM, dan Departemen Sosial dan Catpil. Akan tetapi masih terdapat sebelas SKPD yang skor efisiensi relatifnya di bawah 100 persen. SKPD tersebut antara lain Sekretariat DPRD 42,92 persen, Biro Umum 42,23 persen, Dinas Pekerjaan Umum 42,69 persen, Dinas Perhubungan dan KOMINFO 41,88 persen, Dinas Kesehatan 67,65 persen, Rumah Sakit Umum Daerah 97,63 persen, Dinas Pendidikan dan Olahraga 93,53 persen, Dinas Tenaga Kerja dan Transmigrasi 56,36 persen, Dinas Kebudayaan dan Pariwisata 80,94 persen, Badan Kepegawaian Daerah dan Diklat 62,89 persen, Badan Perpustakaan Daerah dan Arsip 53,60 persen. Kesebelas SKPD ini masih dikatagorikan sebagai SKPD yang mengalami inefisiensi dalam mengelola dan memanfaatkan aset tetap (tanah dan bangunan). Contstant return to scale (CRS) merupakan perbandingan nilai input dan output bersifat konstan, penambahan nilai input dan output sebanding. Nilainilai efisiensi pengukuran kinerja CRS disebut nilai efisiensi teknis murni (pure technical efficiency), hal ini terkait dengan nlai-nilai yang diperoleh dari model yang memperbolehkan variabel return to scale, sehingga skala yang ada dapat tereliminasi. Secara umum nilai efisiensi CRS untuk tiap Decission Making Unit/DMU tidak akan melebihi nilai efisiensi Variable Return to Scale (VRS), hal tersebut dapat dilihat pada Tabel. Tabel diatas menunjukkan adanya perbedaan antara nilai-nilai CRS dan VRS masing-masing SKPD, yang mana nilai CRS tidak melebihi nilai VRS, sehingga pada keteranganpun dijelaskan bahwa masingmasing SKPD mengalamai peningkatan proporsi (Increasing Return to Scale/IRS) dan tidak terdapat satu SKPD yang mengalami penurunan proporsi (Decreasing Return to Scale/DRS).

Variable Return to Scale (VRS) merupakan peningkatan input dan output tidak berproporsi sama, yang mana peningkatan proporsi bisa bersifat Increasing Retur to Scale (IRS) maupun Decreasing Return to Scale (DRS). Namun pada Tabel 3.3 peneliti hanya menunjukkan perbedaan skor antara CRS dan VRS semata. Dalam penelitian ini dapat dilihat bahwa pada Tabel diatas nilai efisiensi relatif CRS dan VRS mengalami peningkatan proporsi dan tidak terdapat satu SKPD pun yang mengalami penurunan proporsi. Artinya perhitungan DEA mengindikasikan bahwa masing-masing SKPD mengalami peningkatan economic scale. 


\section{Skenario perbaikan berdasarkan skor efisiensi.}

Santoso (2009) menyatakan bahwa DEA mampu memberikan nilai perbaikan pada unit yang mengalami inefisiensi (Wahyuni, 2017: 57). SKPD yang mengalami inefisiensi dapat dicarikan nilai perbaikannya. Perhitungan dengan menggunakan DEA dapat memaksimalkan output dan meminimalkan input. Pada penelitian ini hasil perhitungan DEA menunjukkan perbaikan dengan alternatif masing-masing SKPD dalam meminimalkan inputnya.

Nilai perbaikan berdasarkan skor efisiensi relatif pada sebelas SKPD pada Pemerintah Daerah Provinsi NTB adalah sebagai berikut.

1. Berdasarkan hasil perhitungan DEA bahwa nilai efisiensi relatif yang diperoleh Dinas Perhubungan KOMINFO Provinsi NTB adalah 41,88 persen. Melalu perhitungan terperinci diketahui bahwa pada Dinas Perhubungan KOMINFO Provinsi NTB actual nilai aset tetap (tanah dan bangunan) sebesar Rp70.437.761.255, sementara angka target sesuai dengan DEA berjumlah Rp13.392.341.365. Hasil perhitungan DEA menunjukkan bahwa nilai to gain sebesar 81,0 persen dan achieved nya sebesar 19,0 persen, Artinya Dinas Perhubungan KOMINFO masih mengejar 81,0 persen lagi supaya mampu mendapatkan nilai efisiensi relatif sebesar 100 persen. Target PAD dapat dilihat bahwa angka actual nya berjumlah Rp807.301.000, sementara angka targetnya sesuai dengan DEA Rp338.137.300, artinya dari jumlah actual sebesar itu mampu untuk mendapatkan sebesar 58,1 persen, akan tetapi baru tercapai hanya 41,9 persen, Artinya Dinas Perhubungan KOMINFO masih mengejar 58,1 persen lagi supaya mampu mencapai efisiensi relatif 100 persen. Dari hasil perhitungan ini perhitungan DEA menganjurkan untuk lebih mengoptimalkan aset tetapnya karena hasil DEA membuktikan masih jauh dari to gain, begitu juga dengan target PAD tidak terlalu menargetkan PAD sejumlah tersebut. Penjelasan ini dapat dilihat dari tabel berikut.

Tabel Nilai Efisiensi Relatif untuk Dinas Perhubungan KOMINFO Provinsi NTB

\begin{tabular}{l|l|rrrr}
\hline \multicolumn{2}{|c|}{ Variabel } & \multicolumn{1}{c}{ Actual } & \multicolumn{1}{c}{ Target } & to Gain & Achieved \\
\hline Input & NAT(T dan B) & 70437761255.0 & 13392341365.0 & $81.0 \%$ & $19.0 \%$ \\
& Target PAD & 807301000.0 & 338137300.4 & $58.1 \%$ & $41.9 \%$ \\
\hline Output & Realisasi PAD & 519340005.0 & 519340005.0 & $0.0 \%$ & $100 \%$ \\
\hline
\end{tabular}

Sumber: Hasil Perhitungan DEA (data diolah)

2. Berdasarkan hasil perhitungan DEA bahwa nilai efisiensi relatif yang diperoleh Biro Umum Provinsi NTB adalah 42,23 persen. Melalu perhitungan terperinci diketahui bahwa pada Biro Umum Provinsi NTB bahwa actual nilai aset tetap (tanah dan bangunan) sebesar Rp288.766.657.290,0, sementara angka target sesuai dengan DEA berjumlah Rp111.447.590.980,0. Hasil perhitungan DEA menunjukkan bahwa nilai to gain sebesar 96,1 persen dan achieved nya sebesar 3,9 persen. Artinya Biro Umum Provinsi NTB masih mengejar 96,1 persen lagi supaya mampu mendapatkan nilai efisiensi relatif sebesar 100 persen. Target PAD dapat dilihat bahwa angka actual nya berjumlah Rp2.370.740.556, sementara angka targetnya sesuai dengan DEA Rp1.001.126.289,5, artinya dari jumlah actual sebesar itu mampu untuk mendapatkan sebesar 57,8 persen, akan tetapi baru tercapai hanya 42,2 persen. Artinya Biro Umum Provinsi NTB masih mengejar 58 persen supaya 
mampu mendapatkan nilai efisiensi relatif sebesar 100 persen. Dari hasil perhitungan ini perhitungan DEA menganjurkan untuk lebih mengoptimalkan aset tetapnya karena hasil DEA membuktikan masih jauh dari to gain, begitu juga dengan target PAD tidak terlalu menargetkan PAD sejumlah tersebut. Penjelasan ini dapat dilihat dari tabel berikut.

Tabel Nilai Efisiensi Relatif untuk Biro Umum Provinsi NTB

\begin{tabular}{l|l|rrrc}
\hline \multicolumn{2}{|c|}{ Variabel } & \multicolumn{1}{c}{ Actual } & \multicolumn{1}{c}{ Target } & \multicolumn{1}{c}{ to Gain } & Achieved \\
\hline Input & NAT(TdanB) & 288766657290.0 & 11144759098.0 & $96.1 \%$ & $3.9 \%$ \\
& Target PAD & 2370740556.0 & 1001126289.5 & $57.8 \%$ & $42.2 \%$ \\
\hline Output & Realisasi PAD & 1255483310.0 & 1255483310.0 & $0.0 \%$ & $100.0 \%$ \\
\hline
\end{tabular}

Sumber: Hasil Perhitungan DEA (data diolah)

3. Berdasarkan hasil perhitungan DEA bahwa nilai efisiensi relatif yang diperoleh Dinas Pekerjaan Umum (PU) Provinsi NTB adalah 42,69 persen. Melalui perhitungan terperinci diketahui bahwa pada Biro Umum Provinsi NTB bahwa actual nilai aset tetap (tanah dan bangunan) sebesar Rp76.754.259.048,0, sementara angka target sesuai dengan DEA berjumlah Rp12.146.651.668,0. Hasil perhitungan DEA menunjukkan bahwa nilai to gain sebesar 84,2 persen dan achieved nya sebesar 3,9 persen. Artinya bahwa Dinas PU masih mengejar 84.2 persen lagi supaya mampu mendapatkan nilai efisiensi relatif sebesar 100 persen. Target PAD dapat dilihat bahwa angka actual nya berjumlah Rp1.652.875.000, sementara angka targetnya sesuai dengan DEA Rp705.589.279,5, artinya dari jumlah actual sebesar itu mampu untuk mendapatkan sebesar 57,3 persen, akan tetapi baru tercapai hanya 42,7 persen. Artinya Dinas PU masih mengejar 57.3 persen lagi supaya mampu mendapatkan nilai efisiensi relatif sebesar 100 persen. Dari hasil perhitungan ini perhitungan DEA menganjurkan untuk lebih mengoptimalkan aset tetapnya karena hasil DEA membuktikan masih jauh dari to gain, begitu juga dengan target PAD tidak terlalu menargetkan PAD sejumlah tersebut. Penjelasan ini dapat dilihat dari tabel berikut.

Tabel

Nilai Efisiensi Relatif untuk Dinas Pekerjaan Umum (PU) Provinsi NTB

\begin{tabular}{l|l|rrrr}
\hline \multicolumn{2}{l|}{ Variabel } & \multicolumn{1}{c}{ Actual } & \multicolumn{1}{c}{ Target } & \multicolumn{1}{c}{ to Gain } & Achieved \\
\hline \multirow{2}{*}{ Input } & NAT(TdanB) & 76754259048.0 & 12146651668.0 & $84.2 \%$ & $15.8 \%$ \\
& TargetPAD & 1652875000.0 & 705589279.9 & $57.3 \%$ & $42.7 \%$ \\
\hline Output & RealisasiPAD & 927336697.3 & 927336697.3 & $0.0 \%$ & $100 \%$ \\
\hline
\end{tabular}

Sumber: Hasil Perhitungan DEA (data diolah)

4. Berdasarkan hasil perhitungan DEA bahwa nilai efisiensi relatif yang diperoleh Sekretariat DPRD Provinsi NTB adalah 42,92 persen. Melalu perhitungan terperinci diketahui bahwa pada Sekretariat DPRD Provinsi NTB bahwa actual nilai aset tetap (tanah dan bangunan) sebesar Rp33.542.173.992.0, sementara angka target sesuai dengan DEA berjumlah Rp12.577.744.689.0. Hasil perhitungan DEA menunjukkan nilai to gain sebesar 62,5 persen dan achieved nya sebesar 37,5 persen. Artinya Sekretariat DPRD masih mengejar 62,5 persen lagi supaya mampu mencapai nilai efisiensi relatif sebesar 100 persen. Target PAD dapat dilihat bahwa angka actual nya berjumlah Rp1.347.635.716.0, sementara angka targetnya sesuai dengan DEA Rp578.426.002.8, artinya dari jumlah actual sebesar itu mampu untuk mendapatkan sebesar 57,1 persen, akan tetapi baru tercapai hanya 
42,9 persen. Artinya Sekretariat DPRD masih mengejar 57,1 persen lagi supaya mampu mencapai nilai efisiensi relatif sebesar 100 persen. Dari hasil perhitungan ini perhitungan DEA menganjurkan untuk lebih mengoptimalkan aset tetapnya karena hasil DEA membuktikan masih jauh dari to gain, begitu juga dengan target PAD tidak terlalu menargetkan PAD sejumlah tersebut. Penjelasan ini dapat dilihat dari tabel berikut.

Tabel

Nilai Efisiensi Relatif untuk Sekretariat DPRD Provinsi NTB

\begin{tabular}{l|l|rrrr}
\hline \multicolumn{2}{|c|}{ Variabel } & \multicolumn{1}{c}{ Actual } & \multicolumn{1}{c}{ Target } & to Gain & Achieved \\
\hline Input & NAT(TdanB) & 33542173992.9 & 12577744689.0 & $62.5 \%$ & $37.5 \%$ \\
& Target PAD & 1347635716.0 & 578426002.8 & $57.1 \%$ & $42.9 \%$ \\
\hline Output & Realisasi PAD & 786142203.0 & 786142203.0 & $0.0 \%$ & $100.0 \%$ \\
\hline
\end{tabular}

Sumber: Hasil Perhitungan DEA (data diolah)

5. Berdasarkan hasil perhitungan DEA bahwa nilai efisiensi relatif yang diperoleh Badan Perpustakaan Daerah dan Arsip Provinsi NTB adalah 53,60 persen. Melalu perhitungan terperinci diketahui bahwa pada Badan Perpustakaan Daerah dan Arsip Provinsi NTB bahwa actual nilai aset tetap (tanah dan bangunan) sebesar Rp16.690.666.506.0, sementara angka target sesuai dengan DEA berjumlah Rp5.250.019.984.1. Hasil DEA juga menunjukkan bahwa to gain sebesar 68.5 persen dari nilai asetnya, akan tetapi baru tercapai sebesar 31,5 persen. Artinya SKPD ini masih mengejar 68,5 persen lagu supaya mampu mencapai nilai efisiensi relatif sebesar 100 persen. Target PAD dapat dilihat bahwa angka actual nya berjumlah Rp100.000.000.0, sementara angka targetnya sesuai dengan DEA Rp53.602.755.7, artinya dari jumlah actual sebesar itu mampu untuk mendapatkan sebesar 46,4 persen, dan sudah tercapai sebesar 53,6 persen. Maka dari itu SKPD ini masih mengejar 46,4 persen lagi supaya mampu mencapai nilai efisiensi relatif sebesar 100 persen. Dari hasil perhitungan ini perhitungan DEA menganjurkan untuk lebih mengoptimalkan pengelolaan aset tetapnya karena hasil DEA membuktikan masih jauh dari to gain, sedangkan PAD sudah melebihi targetnya. Penjelasan ini dapat dilihat dari Tabel berikut.

Tabel

Nilai Efisiensi Relatif untuk Badan Perpustakaan Daerah dan Arsip Provinsi NTB

\begin{tabular}{l|l|rrrr}
\hline \multicolumn{2}{c|}{ Variabel } & \multicolumn{1}{c}{$\begin{array}{c}\text { Actual } \\
\text { Achieved }\end{array}$} & \multicolumn{1}{c}{ Target } & to Gain & \\
\hline Input & NAT(TdanB) & 16690666506.0 & 5250019984.1 & $68.5 \%$ & $31.5 \%$ \\
& Target PAD & 100000000.0 & 53602755.7 & $56.4 \%$ & $53.6 \%$ \\
\hline Output & Realisasi PAD & 100149783.9 & 100149783.0 & $0.0 \%$ & \\
& & $100.0 \%$ & & & \\
\hline
\end{tabular}

Sumber: Hasil Perhitungan DEA (data diolah)

6. Berdasarkan hasil perhitungan DEA bahwa nilai efisiensi relatif yang diperoleh Dinas Tenaga Kerja dan Transmigrasi Provinsi NTB adalah 56,36 persen. Melalui perhitungan terperinci diketahui bahwa pada Badan Perpustakaan Daerah dan Arsip Provinsi NTB bahwa actual nilai aset tetap (tanah dan bangunan) sebesar Rp22.230.833.700.0, sementara angka target sesuai dengan DEA berjumlah Rp12.529.655.878.0. Artinya bahwa sebenarnya Perpustakaan Daerah dan Arsip Provinsi NTB mampu untuk mendapatkan (to gain) sebesar 43,6 persen dari nilai 
asetnya, sudah tercapai sebesar 56,4 persen. Artinya SKPD ini masih mengejar 43,6 persen lagi supaya mampu mencapai nilai efisiensi relatif sebesar 100 persen. Target PAD dapat dilihat bahwa angka actual nya berjumlah Rp601.173.200.0, sementara angka targetnya sesuai dengan DEA Rp338.830.896.8, artinya dari jumlah actual sebesar itu mendapatkan sebesar 43,6 persen dan tercapai sebesar 53,6 persen, dan untuk mencapai nilai efisiensi relatif SKPD ini masih mengejar 43,6 persen lagi supaya mampu mencapai nilai efisiensi relatif sebesar 100 persen. Dari hasil perhitungan ini perhitungan DEA menganjurkan untuk lebih mengoptimalkan pengelolaan aset tetapnya karena hasil DEA membuktikan masih jauh dari to gain, sedangkan PAD sudah melebihi targetnya. Penjelasan ini dapat dilihat dari Tabel berikut.

Tabel

Nilai Efisiensi Relatif untuk Dinas Tenaga Kerja dan Transmigrasi Provinsi NTB

\begin{tabular}{l|l|rrrr}
\hline \multicolumn{2}{c|}{ Variabel } & \multicolumn{1}{c}{$\begin{array}{c}\text { Actual } \\
\text { Achieved }\end{array}$} & Target & to Gain & \\
\hline Input & NAT(TdanB) & 22230833700.0 & 12529655878.0 & $43.6 \%$ & $56.4 \%$ \\
& Target PAD & 601173200.0 & 338830896.8 & $43.6 \%$ & $56.4 \%$ \\
\hline Output & Realisasi PAD & 510521700.0 & 510521700.0 & $0.0 \%$ & $100.0 \%$ \\
\hline
\end{tabular}

Sumber: Hasil Perhitungan DEA (data diolah)

7. Berdasarkan hasil perhitungan DEA bahwa nilai efisiensi relatif yang diperoleh Badan Kepegawaian Daerah dan Diklat Provinsi NTB adalah 62,89 persen. Melalu perhitungan terperinci diketahui bahwa pada Badan Perpustakaan Daerah dan Arsip Provinsi NTB bahwa actual nilai aset tetap (tanah dan bangunan) sebesar Rp15.175.875.932.0, sementara angka target sesuai dengan DEA berjumlah Rp9.544.404.605.9. Dalam perhitungan ini dapat dilihat bahwa to gain sebesar 37,1 persen dari nilai asetnya dan sudah tercapai sebesar 62,9 persen. Artinya SKPD ini masih mengejar 37,1 persen lagi supaya mampu mencapai nilai efisiensi relatif sebesar 100 persen. Target PAD dapat dilihat bahwa angka actual nya berjumlah Rp300.000.000, sementara angka targetnya sesuai dengan DEA Rp188.675.856.0, to gain nya sebesar 37,1 persen, dan sudah tercapai 62,9 persen. Untuk mencapai nilai efisiensi relatif SKPD ini masih mengejar 37,1 persen untuk mencapainya. Dari hasil perhitungan ini perhitungan DEA menganjurkan untuk lebih mengoptimalkan pengelolaan aset tetapnya karena hasil DEA membuktikan masih jauh dari to gain, sedangkan PAD sudah melebihi targetnya. Penjelasan ini dapat dilihat dari Tabel berikut.

Tabel

Nilai Efisiensi Relatif untuk Badan Kepegawaian Daerah dan Diklat Provinsi NTB

\begin{tabular}{l|l|lll}
\hline \multicolumn{2}{c|}{ Variabel } & \multicolumn{1}{c}{$\begin{array}{c}\text { Actual } \\
\text { Achieved }\end{array}$} & Target & to Gain \\
\hline Input & NAT(TdanB) & 15175875932.0 & 9544404605.9 & $37.1 \%$ \\
& Target PAD & $\begin{array}{l}62.9 \% \\
300000000.0\end{array}$ & 188675856.0 & $37.1 \%$ \\
& & $62.9 \%$ & & \\
\hline Output & Realisasi PAD & $\begin{array}{l}304042000.0 \\
\text { 100.0\% }\end{array}$ & 304042000.0 & $0.0 \%$ \\
& & & & \\
\hline
\end{tabular}


Sumber: Hasil Perhitungan DEA (data diolah)

8. Berdasarkan hasil perhitungan DEA bahwa nilai efisiensi relatif yang diperoleh Dinas Kesehatan (Dikes) Provinsi NTB adalah 67,65 persen. Melalui perhitungan terperinci diketahui bahwa pada Dinas Kesehatan (Dikes) Provinsi NTB bahwa actual nilai aset tetap (tanah dan bangunan) sebesar Rp3.971.639.000,0, sementara angka target sesuai dengan DEA berjumlah Rp2.686.748.941,1. artinya bahwa sebenarnya Dinas Kesehatan (Dikes. Hasil DEA menunjukkan bahwa nilai to gain sebesar 32,4 persen dari nilai asetnya dan achieved nnya sebesar 67,6 persen. Artinya SKPD ini masih mengejar 32,4 persen supaya mampu mencapai nilai efisiensi relatif sebesar 100 persen. Target PAD dapat dilihat bahwa angka actual nya berjumlah Rp3.441.450.860.0, sementara angka targetnya sesuai dengan DEA Rp2.328.085.320.0, artinya dari jumlah actual sebesar itu mampu untuk mendapatkan sebesar 32,4 persen dan sudah tercapai sebesar 67,6 persen. Artinya SKPD ini masih mengejar 32,4 persen supaya mampu mencapai nilai efisiensi relatif sebesar 100 persen Dari hasil perhitungan ini perhitungan DEA menganjurkan untuk lebih mengoptimalkan pengelolaan aset tetapnya karena hasil DEA membuktikan masih jauh dari to gain, sedangkan PAD sudah melebihi targetnya. Penjelasan ini dapat dilihat dari Tabel berikut.

Tabel

Nilai Efisiensi Relatif untuk Dinas Kesehatan (Dikes) Provinsi NTB

\begin{tabular}{l|l|ccrc}
\hline \multicolumn{2}{|c|}{ Variabel } & Actual & Target & to Gain & Achieved \\
\hline Input & NAT(TdanB) & 3971639000.0 & 2686748941.1 & $32.4 \%$ & $67.6 \%$ \\
& Target PAD & 3441450860.0 & 2328085320.0 & $32.4 \%$ & $67.6 \%$ \\
\hline Output & Realisasi PAD & 2684730333.0 & 2684730333.0 & $0.0 \%$ & $100.0 \%$ \\
\hline
\end{tabular}

Sumber: Hasil Perhitungan DEA (data diolah)

9. Berdasarkan hasil perhitungan DEA bahwa nilai efisiensi relatif yang diperoleh Dinas Kebudayaan dan Pariwisata Provinsi NTB adalah 80,94 persen. Melalui perhitungan terperinci diketahui bahwa pada Dinas Kebudayaan dan Pariwisata Provinsi NTB bahwa actual nilai aset tetap (tanah dan bangunan) sebesar Rp4.491.097.000.0, sementara angka target sesuai dengan hasil DEA berjumlah Rp3.634.901.593.0. Hasil perhitungan DEA diperoleh nilai to gain sebesar 19,1 persen dan nilai achieved nya sebesar 80,9 persen. Artinya SKPD ini masih mengejar 19,1 persen lagi supaya mampu mencapai nilai efisiensi relatif sebesar 100 persen. Target PAD dapat dilihat bahwa angka actual nya berjumlah Rp87.680.000.0, sementara angka targetnya sesuai dengan DEA Rp70.964.437.4, hasil perhitungan DEA nilai to gain sebesar 19,1 persen, nilai achieved nya sebesar 80,9 persen. Artinya SKPD ini masih mengejar 19,1 persen lagi supaya mampu mencapai nilai efisiensi relatif sebesar 100 persen. Dari hasil perhitungan ini perhitungan DEA menganjurkan untuk lebih mengoptimalkan pengelolaan aset tetapnya karena hasil DEA membuktikan masih jauh dari to gain, sedangkan PAD sudah melebihi targetnya, akan tetapi belum dikatakan efisiensi relatif. Penjelasan ini dapat dilihat dari Tabel berikut.

Tabel

Nilai Efisiensi Relatif untuk Dinas Kebudayaan dan Pariwisata Provinsi NTB

\begin{tabular}{c|ccc}
\hline Variabel & Actual & Target & to Gain Achieved \\
\hline
\end{tabular}




\begin{tabular}{l|l|rrrr}
\hline \multirow{2}{*}{ Input } & NAT(TdanB) & 4491097000.0 & 3634901593.6 & $19.1 \%$ & $80.9 \%$ \\
& Target PAD & 87680000.0 & 70964437.4 & $19.1 \%$ & $80.9 \%$ \\
\hline Output & Realisasi & 102788556.0 & 102788556.0 & $0.0 \%$ & \\
& PAD & $100.0 \%$ & & & \\
\hline
\end{tabular}

Sumber: Hasil Perhitungan DEA (data diolah)

10. Berdasarkan hasil perhitungan DEA bahwa nilai efisiensi relatif yang diperoleh Dinas Pendidikan dan Olahraga (Dikpora) Provinsi NTB adalah 93,53 persen. Melalui perhitungan terperinci diketahui bahwa pada Dinas Pendidikan dan Olahraga (Dikpora) Provinsi NTB bahwa actual nilai aset tetap (tanah dan bangunan) sebesar Rp6.293.132.000.0, sementara angka target sesuai dengan hasil DEA berjumlah Rp5.885.725.906.6. Hasil perhitungan DEA menunjukkan bahwa nilai to gain sebesar 6,5 persen, dan achieved nya 93,5 persen. Artinya SKPD ini masih mengejar 6,5 persen lagi supaya mampu mencapai nilai efisiensi relatif sebesar 100 persen. Target PAD dapat dilihat bahwa angka actual nya berjumlah Rp83.320.000.0, sementara angka targetnya sesuai dengan DEA Rp77.926.012.4, Hasil perhitungan DEA nilai to gain sebesar 6,5 persen, dan achieved nya sebesar 93,5 persen. Artinya SKPD ini masih mengejar 6,5 persen lagi supaya mampu mencapai nilai efisiensi relatif sebesar 100 persen. Dari hasil perhitungan ini perhitungan DEA menganjurkan untuk lebih mengoptimalkan pengelolaan aset tetapnya dan PAD sudah melebihi targetnya, akan tetapi masih belum dikatagorikan sebagai SKPD yang sudah efisien relatif. Penjelasan ini dapat dilihat dari Tabel berikut.

Tabel

Nilai Efisiensi Relatif untuk Dinas Pendidikan dan Olahraga (Dikpora)

Provinsi NTB

\begin{tabular}{l|l|rrrc}
\hline \multicolumn{2}{|c|}{ Variabel } & \multicolumn{1}{c}{ Actual } & Target & to Gain & Achieved \\
\hline Input & NAT(TdanB) & 6293132000.0 & 83320000.0 & $6.5 \%$ & $93.5 \%$ \\
& Target PAD & 5885725906.6 & 77926012.4 & $6.5 \%$ & $93.5 \%$ \\
\hline Output & Realisasi PAD & 135369090.0 & 135369090.0 & $0.0 \%$ & $100.0 \%$ \\
\hline
\end{tabular}

Sumber: Hasil Perhitungan DEA (data diolah)

11. Berdasarkan hasil perhitungan DEA bahwa nilai efisiensi relatif yang diperoleh Rumah Sakit Umum Daerah Provinsi NTB adalah 97,63 persen. Melalui perhitungan terperinci diketahui bahwa pada Dinas Pendidikan dan Olahraga (Dikpora) Provinsi NTB bahwa actual nilai aset tetap (tanah dan bangunan) sebesar Rp43.743.634.150.0, sementara angka target sesuai dengan DEA berjumlah Rp2.867.353.083.6. Hasil perhitungan DEA nilai to gain sebesar 93,4 persen, dan achieved nya 6,6 persen. Artinya SKPD ini masih mengejar 93,4 persen lagi supaya mampu mencapai nilai efisiensi relatif sebesar 100 persen. Target PAD dapat dilihat bahwa angka actual nya berjumlah Rp52.631.579.000.0, sementara angka targetnya sesuai dengan DEA Rp51.383.244.661.0. Hasil perhitungan DEA nilai to gain sebesar 2,4 persen, dan achieved nya 97,6 persen. Artinya SKPD ini cukup mengejar 2,4 persen lagi supaya mampu mencapai nilai efisiensi relatif sebesar 100 persen. Dari hasil perhitungan ini perhitungan DEA menganjurkan untuk lebih mengoptimalkan pengelolaan aset tetapnya karena hasil DEA membuktikan masih jauh dari to gain, sedangkan PAD sudah melebihi targetnya namun belum dikatagorikan sebagai SKPD yang efisien relatif. Penjelasan ini dapat dilihat dari Tabel berikut. 
Tabel

Nilai Efisiensi Relatif untuk Rumah Sakit Umum Daerah Provinsi NTB

\begin{tabular}{l|l|lrrc}
\hline \multicolumn{2}{c|}{ Variabel } & \multicolumn{1}{c}{ Actual } & Target & to Gain & Achieved \\
\hline Input & NAT(TdanB) & 43743634150.0 & & $93.4 \%$ & $6.6 \%$ \\
& Target PAD & 2867353083.6 & & $2.4 \%$ & $97.6 \%$ \\
& & 52631579000.0 & & \\
& & 51383244661.0 & & & \\
\hline Output & Realisasi PAD & 52027661439.0 & 52027661439.0 & $0.0 \%$ & $100.0 \%$ \\
\hline
\end{tabular}

Sumber: Hasil Perhitungan DEA (data diolah)

Interpretasi hasil penelitian

\section{Hasil perhitungan Data Envelopment Analysis (DEA).}

Dari hasil perhitungan data envelopment analysis (DEA) menunjukkan bahwa dari 17 (tujuh belas) SKPD terdapat 6 (enam) SKPD yang efisien relatif pada tahun 2017 dalam mengelola dan memanfaatkan aset tetap (tanah dan bangunan) yaitu Badan Perencanaan Pembangunan Daerah (BAPPEDA), Dinas Pendapatan Daerah (DISPENDA), Departemen Sosial Kependudukan dan Catpil (Depsoskep dan Catpil), Rumah Sakit Jiwa (RSJ), Badan Lingkungan Hidup (BLHP), dan Dinas Koperasi dan UMKM.

Keenam SKPD ini dikatagorikan sebagai SKPD yang mampu mengoptimalkan mengelola dan memanfaatkan aset tetapnya dengan optimal secara relatif telah mampu menggunakan input yang dimiliki, sehingga mampu menghasilkan output yang optimal (100 persen) dan tidak lagi melakukan pemborosan dalam menggunakan input. Pencapaian tersebut tidak terlepas dari usaha dan kerja kerja dari masingmasing SKPD terutama pada bagian pengelola atau pengurus barang dalam mewujudkan pemanfaatan aset yang optimal dan efisien. Pencapaian tersebut tentunya harus bisa dipertahankan oleh SKPD yang terkait, jangan sampai pada periode berikutnya mengalami inefisiensi.

Dari hasil perhitungan DEA juga terdapat sebelas SKPD yang mengalami inefisiensi dengan nilai efisiensi $<100$ persen. SKPD tersebut antara lain Dephubkominfo (41,88 persen), Biro Umum (42,23 persen), Dinas PU (42,69 persen), Setda DPRD (42,92 persen), Bapusda dan Arsip (53,60 persen), Disnakertrans (56,36 persen), BKD dan Diklat (62,89 persen), Dinas Kesehatan (67,65 persen), Disbudpar (80,94 persen), Dikpora (93,53), dan RSUD (97,63 persen).

Berikut adalah penjelasan dari SKPD yang mengalami inefisiensi sebagai berikut.

1) Dinas Perhubungan KOMINFO dengan nilai aset tetap (tanah dan bangunan) sebesar Rp70.437.761.255 menghasilkan realisasi pendapatan asli daerah sebesar Rp519.340.035. Hasil perhitungan DEA menunjukkan nilai efisiensi relatifnya sebesar 41,88 persen dan masih mengejar 58,2 persen lagi supaya mampu mencapai nilai efisiensi relatif. Artinya Dinas Perhubungan KOMINFO belum mampu mencapai efisien relatif sebesar 100 persen, sehingga dapat disimpulkan bahwa belum dikatagorikan sebagai SKPD yang belum mampu mengoptimalkan pengelolaan dan pemanfaatan aset tetap (tanah dan bangunan).

2) Biro Umum dengan nilai aset tetap (tanah dan bangunan) sebesar Rp288.766.657.290 menghasilkan realisasi pendapatan asli daerah sebesar Rp1.255.483.310, hasil perhitungan DEA menunjukkan nilai efisiensi relatifnya sebesar 42,23 persen dan masih mengejar 57,77 persen lagi supaya mampu 
mencapai nilai efisiensi relatif. Artinya Biro Umum belum mampu mencapai efisien relatif sebesar 100 persen, sehingga dapat disimpulkan bahwa belum dikatagorikan sebagai SKPD yang mampu mengoptimalkan pengelolaan dan pemanfaatan aset tetap (tanah dan bangunan).

3) Dinas Pekerjaan Umum (PU) dengan nilai aset tetap (tanah dan bangunan) sebesar Rp76.754.259.048 menghasilkan realisasi pendapatan asli daerah sebesar Rp927.336.697, hasil perhitungan DEA menunjukkan nilai efisiensi relatifnya sebesar 42,69 persen dan masih mengejar 57,31 persen lagi supaya mampu mencapai nilai efisiensi relatif. Artinya Dinas Pekerjaan Umum belum mampu mencapai efisien relatif sebesar 100 persen, sehingga dapat disimpulkan bahwa belum dikatagorikan sebagai SKPD yang mampu mengoptimalkan pengelolaan dan pemanfaatan aset tetap (tanah dan bangunan).

4) Sekretariat DPRD dengan nilai aset tetap (tanah dan bangunan) sebesar Rp33.542.173.992 menghasilkan realisasi pendapatan asli daerah sebesar Rp786.142.203, hasil perhitungan DEA menunjukkan nilai efisiensi relatifnya sebesar 42,92 persen dan masih mengejar 57,8 persen lagi supaya mampu mencapai nilai efisiensi relatif. Artinya Sekretariat DPRD belum mampu mencapai efisien relatif sebesar 100 persen, sehingga dapat disimpulkan bahwa belum dikatagorikan sebagai SKPD yang mampu mengoptimalkan pengelolaan dan pemanfaatan aset tetap (tanah dan bangunan).

5) Badan Perpustakaan Daerah dan Arsip dengan nilai aset tetap (tanah dan bangunan) sebesar Rp16.690.666.506 menghasilkan realisasi pendapatan asli daerah sebesar Rp100.149.783, hasil perhitungan DEA menunjukkan nilai efisiensi relatifnya sebesar 53,60 persen dan masih mengejar 43,4 persen lagi supaya mampu mencapai nilai efisiensi relatif. Artinya Badan Perpustakaan Daerah dan Arsip belum mampu mencapai efisien relatif sebesar 100 persen, sehingga dapat disimpulkan bahwa belum dikatagorikan sebagai SKPD yang mampu mengoptimalkan pengelolaan dan pemanfaatan aset tetap (tanah dan bangunan).

6) Dinas Tenaga Kerja dan Transmigrasi dengan nilai aset tetap (tanah dan bangunan) sebesar Rp22.230.833.700 menghasilkan realisasi pendapatan asli daerah sebesar Rp510.521.700, hasil perhitungan DEA menunjukkan nilai efisiensi relatifnya sebesar 56.36 persen dan masih mengejar 43,64 persen lagi supaya mampu mencapai nilai efisiensi relatif. Artinya Dinas Tenaga Kerja dan Transmigrasi belum mampu mencapai efisien relatif sebesar 100 persen, sehingga dapat disimpulkan bahwa dikatagorikan sebagai SKPD yang belum mampu mengoptimalkan pengelolaan dan pemanfaatan aset tetap (tanah dan bangunan).

7) BKD dan Diklat dengan nilai aset tetap (tanah dan bangunan) sebesar Rp15.175.875.932 menghasilkan realisasi pendapatan asli daerah sebesar Rp304.042.000, hasil perhitungan DEA menunjukkan bahwa nilai efisiensi relatifnya sebesar 62,89 persen dan masih mengejar 37,11 persen lagi supaya mampu mencapai nilai efisiensi relatif. Artinya BKD dan Diklat belum mampu mencapai efisien relatif sebesar 100 persen, sehingga dapat disimpulkan dan dikatagorikan sebagai SKPD yang belum mampu mengoptimalkan pengelolaan dan pemanfaatan aset tetap (tanah dan bangunan). 
8) Dinas Kesehatan (Dikes) dengan nilai aset tetap (tanah dan bangunan) sebesar Rp3.971.639.000 menghasilkan realisasi pendapatan asli daerah sebesar Rp2.684.730.333, hasil perhitngan DEA menunjukkan bahwa nilai efisiensi relatifnya sebesar 67,65 persen dan masih mengejar 32,35 persen lagi supaya mampu mencapai nilai efisiensi relatif. Artinya bahwa Dinas Kesehatan (Dinkes) belum mampu mencapai efisien relatif sebesar 100 persen, sehingga dapat disimpulkan bahwa belum dikatagorikan sebagai SKPD yang mampu mengoptimalkan pengelolaan dan pemanfaatan aset tetap (tanah dan bangunan).

9) Dinas Kebudayaan dan Pariwisata dengan nilai aset tetap (tanah dan bangunan) sebesar Rp4.491.097.000 menghasilkan realisasi pendapatan asli daerah sebesar Rp102.788.556, hasil perhitungan DEA menunjukkan nilai efisiensi relatifnya sebesar 80,94 persen dan masih mengejar 19,06 persen lagi supaya mampu mencapai nilai efisiensi relatif. Artinya Dinas Kebudayaan dan Pariwisata belum mampu mencapai efisien relatif sebesar 100 persen, sehingga dapat disimpulkan bahwa dikatagorikan sebagai SKPD yang belum mampu mengoptimalkan pengelolaan dan pemanfaatan aset tetap (tanah dan bangunan).

10) Dinas Pendidikan dan Olahraga (Dikpora) dengan nilai aset tetap (tanah dan bangunan) sebesar Rp6.293.132.000 menghasilkan realisasi pendapatan asli daerah sebesar Rp135.369.090, hasil perhitungan DEA menunjukkan nilai efisiensi relatifnya sebesar 93,53 persen dan masih mengejar 6,47 persen lagi supaya mampu mencapai nilai efisiensi relatif. Artinya Dinas Pendidikan dan Olahraga belum mampu mencapai efisien relatif sebesar 100 persen, sehingga dapat disimpulkan bahwa dikatagorikan sebagai SKPD yang belum mampu mengoptimalkan pengelolaan dan pemanfaatan aset tetap (tanah dan bangunan).

11) Rumah Sakit Umum Daerah (RSUD) dengan nilai aset tetap (tanah dan bangunan) sebesar Rp43.743.634.150 menghasilkan realisasi pendapatan asli daerah sebesar Rp52.027.661.439, hasil perhitungan DEA menunjukkan nilai efisiensi relatifnya sebesar 97,63 persen dan masih mengejar 2,37 persen lagi supaya mampu mencapai nilai efisiensi relatif. Artinya Dinas Pendidikan dan Olahraga (Dikpora) belum mampu mencapai efisien relatif sebesar 100 persen, sehingga dapat disimpulkan bahwa masih dikatagorikan sebagai SKPD yang belum mampu mengoptimalkan pengelolaan dan pemanfaatan aset tetap (tanah dan bangunan).

\section{G. KESIMPULAN DAN SARAN}

Sesuai dengan data dan hasil penelitian bahwa masing-masing SKPD Pemerintah Daerah Provinsi NTB memiliki Nilai aset yang sangat tinggi. Nilai tersebut dikarenakan karena aset-aset yang dikuasai oleh Pemerintah Daerah terletak di daerah/lokasi yang sangat strategis, dan berpeluang besar bahwa aset-aset tersebut untuk bisa dioptimalkan pengelolaan dan pemanfaatanya, agar dapat memberikan kontribusi positif dalam meningkatkan pendapatan Asli Daerah (PAD).

Berdasarkan hasil analisis dengan menggunakan Data Envelopment Analysis (DEA) bahwa dari 17 (tujuh belas) Satuan Kerja Perangkat Daerah (SKPD) Provinsi NTB pada tahun 2017 sesuai dengan perhitungan DEA terdapat 6 (enam) SKPD yang mengalami efisiensi relatif dalam mengelola dan memanfaatkan aset tetap (tanah dan bangunan), SKPD tersebut meliputi: Badan Perencanaan Pembangunan Daerah 
(Bappeda), Dinas Pendapatan Daerah (Dispenda), Departemen Sosial Kependudukan dan Catpil, Rumah Sakit Jiwa (RSJ), Badan Lingkungan Hidup dan Penelitian (BLHP), dan Dinas Koperasi dan UMKM. Keenam SKPD tersebut menurut hasil perhitungan DEA sudah dikatagorikan efisien karena memiliki skor efisiensi 100 persen. Selain itu, juga sesuai dengan perhitungan DEA terdapat 11 (sebelas) SKPD yang mengalami inefisiensi dalam mengoptimalkan pengelolaan dan pemanfaatan aset tetap (tanah dan bangunan). Kesebelas SKPD tersebut meliputi: Dephubkominfo (41,88 persen), Biro Umum (42,23 persen), Dinas PU (42,69 persen), Setda DPRD (42,92 persen), Bapusda dan Arsip (53.60 persen), Disnakertrans (56,36 persen), BKD dan Diklat (62,89 persen), Dinas Kesehatan (67,65 persen), Disbudpar (80,94 persen), Dikpora (93,53), dan RSUD $(97,63$ persen). SKPD-SKPD tersebut dikatakan inefisiensi karena memiliki skor efisiensi $<100$ persen.

\section{H. DAFTAR PUSTAKA}

Avkiran, Necmi K, 1999, "An Application Reference For Data Envelopment Analysis In Branch Banking: Helping The Novice Researcher". International Journal of Bank Marketing.

Budisusilo \& Suryantoro. (2005). "Penilaian Dan Pengelolaan Asset". Makalah.Yogyakarta Cooper, Seiford and Tone. 2003, Data Envelopment Analysis, A Comprehensive Text with Models, Applications, References and DEA-Solver Software. Kluwer Academic Publishers Group, Boston/Dordrecht/London.

Copper, and Schindler. 2006, Business Research Methods, Boston: McGRAW-HILL Irwin.

Doli D. Siregar. (2004). Management Aset Strategi Penataan Konsep Pembangunan Berkelanjutan secara Nasional dalam Konteks Kepala Daerah sebagai CEO's pada Era Globalisasi dan Otonomi Daerah. Jakarta: PT Gramedia Pustaka Utama.

Hambali. (2010). Inventarisasi Barang Milik Negara. Bandung: Politeknik Negeri.

Hasibuan, Malayu, S.P. 2005. Manajemen Sumberdaya Manusia, Edisi Reisi. PT. Bumi Angkasa. Jakarta.Hasting, Nicholas A. Jhon. (2010). Psysical Asset Management.

PAU Studi Ekonomi UGM, 2000, “Modul Pelatihan Metodologi Penelitian DEA”, PAU Studi Ekonomi UGM, Yogyakarta.

Peraturan Menteri Dalam Negeri Nomor 17 Tahun 2007 tentang Pedoman Teknis Pengelolaan Barang Milik Daerah.

Santosa, P.B dan Khariza, A.M, 2009 "Analisis Kinerja Sektor Usaha Tani Padi Melalui Pendekatan Agribisnis", Jurnal organisasi dan Manajemen, Volume 5, Nomor 1, Maret 2009, 35-48.

Sitanggang, Feronika, Evi, 2012. "Analisis Efisiensi Indistri Perbankan: Aplikasi Metoda Data Envelopment Analysist (DEA"). Tesis S2, Program Pascasarjana Magister Manajemen, (digital online).

Martin, Emilio, 2003, "An Application of the Data Envelopment Analysis Methodology in the Performance Assessment of the Zaragoza University Departments". Documento de Trabajo 2003-06, Facultad de Ciencias Económicas y Empresariales Universidad, Department of Accounting and Finance, University of Zaragoza.

Undang-undang Nomor 22 Tahun 1999 diubah dengan Undang-Undang Nomor 32 Tahun 2004 tentang Pemerintahan Daerah.

Wahyuni, Ari, 2017, "Pengaruh Manajemen Aset Terhadap Optimalisasi Aset Tetap Pemerintah Kabupaten Sumbawa Barat". Tesis S2, Program Pascasarjana Magister Manajemen, (digital online). 